\title{
Ultan Qalası: A Fortified Site in the Sasanian Borderlands (Mughan Steppe, Iranian Azerbaijan)
}

\section{Citation}

Alizadeh, Karim. 2011 Ultan Qalası: A Fortified Site in the Sasanian Borderlands (Mughan

Steppe, Iranian Azerbaijan). Iran 49:55-77.

\section{Permanent link}

http://nrs.harvard.edu/urn-3:HUL.InstRepos:11718227

\section{Terms of Use}

This article was downloaded from Harvard University's DASH repository, and is made available under the terms and conditions applicable to Other Posted Material, as set forth at http:// nrs.harvard.edu/urn-3:HUL.InstRepos:dash.current.terms-of-use\#LAA

\section{Share Your Story}

The Harvard community has made this article openly available.

Please share how this access benefits you. Submit a story.

Accessibility 


\title{
ULTAN QALASI: A FORTIFIED SITE IN THE SASANIAN BORDERLANDS (MUGHAN STEPPE, IRANIAN AZERBAIJAN)
}

\author{
By Karim Alizadeh \\ Harvard University
}

\begin{abstract}
Our knowledge of Sasanian imperial strategy continues to grow as a result of a range of projects investigating the frontiers of the Sasanian Empire. Understanding of the north-western fringe of the Empire in particular is being increased by the Mughan Steppe Archaeological Project. Surveys have shown that the fortified settlement of Ultan Qalası is the largest of a series of fortified sites that lie adjacent to irrigation canals that stretch across the steppe, and excavations have provided relative and absolute dating evidence for the establishment of the settlement during the Sasanian period. This paper introduces the Mughan Steppe Archaeological Project and presents the stratigraphy of Ultan Qalası. It also situates this site within the broader socio-political context of the southern Caucasus in the first millennium AD, and the wider world of the Sasanian Empire.
\end{abstract}

Keywords

Ultan Qalası; Sasanian city; Iranian Azerbaijan; southern Caucasus; Mughan Steppe

\section{INTRODUCTION}

The Mughan Steppe Archaeological Project commenced its investigation of the Mughan Steppe (Dasht-e Moghan) region of north-western Iran in 2004 with the excavation of soundings at the site of Ultan Qalası, a fortified settlement on the south bank of the Aras (Araxes) River (Fig. 1). ${ }^{1}$ The project has now conducted three further seasons of excavations at Ultan Qalası, and one season of excavations at the site of Nadir Tepesi, which is a multi-period mound located in the most western part of the steppe. To improve our knowledge of the ancient landscape of the area, a short season of survey on the Mughan Steppe was also undertaken in 2005. This paper will introduce the Mughan Steppe and the work of the Mughan Steppe Archaeological Project, and outline some preliminary results from the excavations at Ultan Qalası. The investigation of this site and its associated infrastructure make an important contribution to our understanding of the broader socio-political context of the southern Caucasus in the first millennium AD. and the nature of Sasanian imperial strategy in this region.

1 Alizadeh 2007b.

\section{THE MUGHAN STEPPE: GEOGRAPHY AND LAND-USE}

The Mughan Steppe is located in the north-east corner of Iranian Azerbaijan, in the northern part of Ardabil province (Fig. 1). The northern boundary of the area is demarcated by the Aras River, which is also the boundary between Iran and the Republic of Azerbaijan in this region. The Qara Su River and Sabalan Mountains form the western and southern boundaries of the steppe respectively (Fig. 1). The Mughan Steppe is a broad, low, flat plain with elevations ranging from around 50 to $200 \mathrm{~m}$ above sea level along the south bank of the Aras River, with the lowest elevations being toward the end of its course where it meets the Kura River in the Republic of Azerbaijan, which in turn flows into the Caspian Sea.'

As the river nears the Caspian Sea, the velocity of its water flow decreases, which might be caused by increases in the rate of sediment deposition. On the south bank of the Aras floodplain, the river is incised about $15 \mathrm{~m}$ into the steppe terrace and at the southern limits of the steppe; the terrain rises to highlands reaching an altitude of $700 \mathrm{~m}$ above sea level, and these ultimately continue into the Sabalan Mountain

2 Hawaiian Agronomics Company International 1971: 8 . 


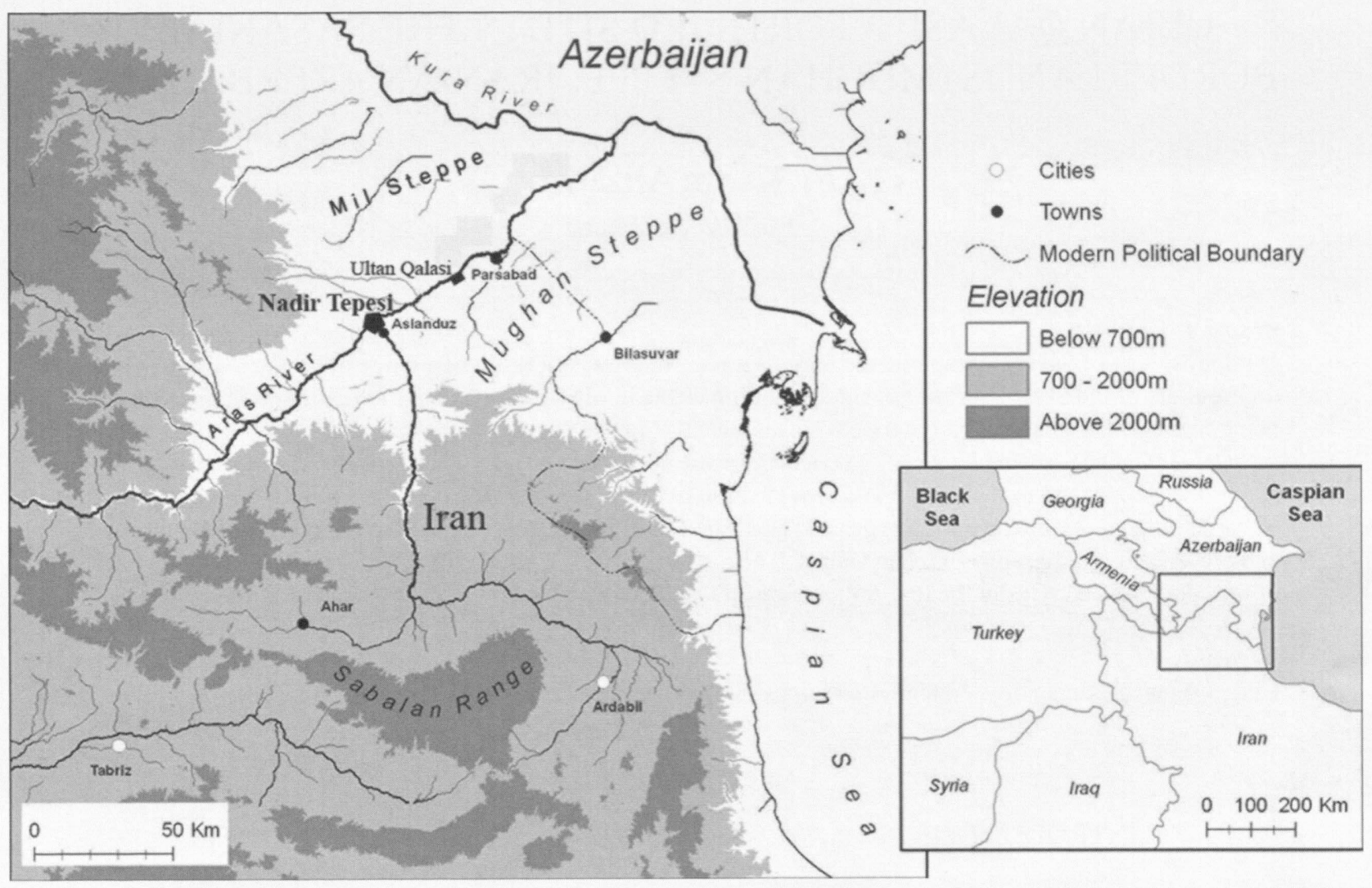

Fig. 1. Location of Mughan Steppe and Ultan Qalast (after Alizadeh and Ur 2007).

range near Ardabil (Fig. 1). ${ }^{3}$ Overall, the soils of the steppe are well-developed and suitable for agriculture, and its topographic characteristics also offer an excellent context for the development of irrigation based agriculture. The geographic and climatic attributes of the region make the Mughan Steppe suitable for utilisation as pasture land and, as will be outlined below, it appears that this was the dominant strategy of landuse between the Early Bronze Age and the Sasanian Period. ${ }^{4}$ Due to these same characteristics, and the fact that it is located close to perennial water sources, the Mughan Steppe was utilised as winter pasture by various tribes during the centuries after the collapse of Sasanian Empire, and most recently by the Shahsevan tribal confederation. 5

3 Schweizer 1974; Tapper 1979: 23-27.

4 Alizadeh 2007a.

5 Tapper 1997: 39.

\section{SETTLEMENT HISTORY}

The survey of the Mughan Steppe undertaken in 2005 by the Mughan Steppe Archaeological Project involved an intensive study of the western part of the steppe around the modern town of Aslanduz. Other areas were investigated using extensive reconnaissance methods.

At present, the earliest occupation of the steppe is poorly understood. An open-air site (MS-030, near Babaxan Qishlaqi village) that lies between the uplands and the steppe was potentially Upper Palaeolithic in date and may represent the earliest archaeological evidence for human settlement in this region. The true date of this site will only be established by targeted excavations. A number of small sites along the Qara Su River, close to its juncture to the Araxes River and not far from Aslanduz town, are characterised by ceramics with chaff temper and a coarse surface. The presence of such material might indicate the existence of preEarly Bronze Age settlements at these locations. It is notable that a small site next to Iydir village, on the 


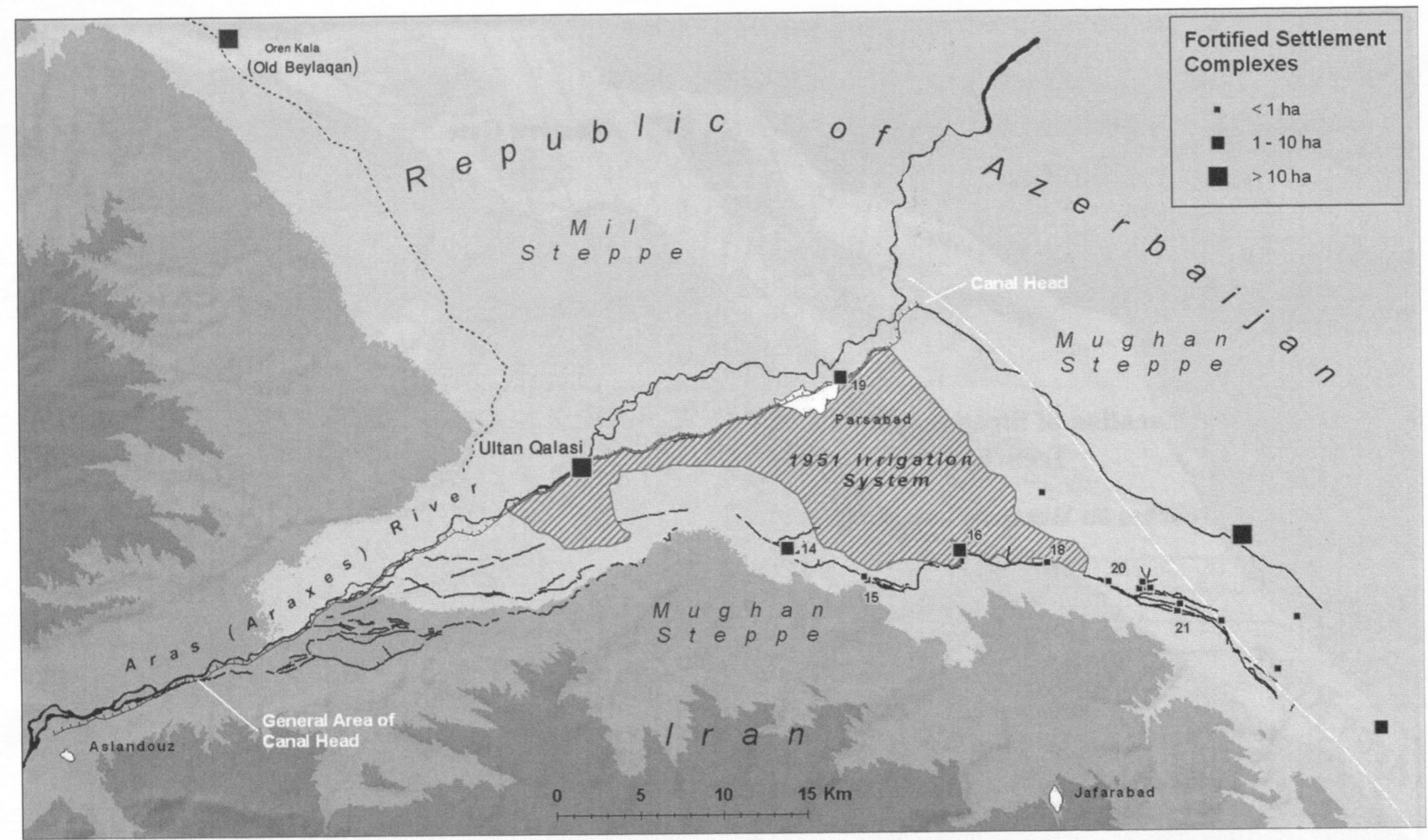

Fig. 2. Ultan Qalasi and other fortified settlements along irrigation canals in Mughan Steppe (after Alizadeh and Ur 2007).

western bank of the Qara Su, known as Iydir Tepesi, was excavated in the early 2000 s by a team from the Iranian Cultural Heritage Organisation of Ardabil and, based on comparative studies of ceramics, Hessari and $\mathrm{H}$. Akbari6 have suggested that the site can be dated to the late Neolithic and Chalcolithic periods.

Early Bronze Age settlements in the area are exemplified by several multi-period tepes, including Nadir Tepesi (MS-042) 7 and Xantepesi (MS-011), which lie along the south bank of Araxes River, and Ilanli Tepesi, which is situated on the bank of Bolghar Chai in the eastern part of the steppe (Fig. 1). These sites are representative of the so-called Kura-Araxes Culture and typical Kura-Araxes ceramics, including black and grey burnished wares, were collected by a survey team from these sites. Preliminary excavations were conducted by the author at the site of Nadir Tepesi in 2007,8 and showed that Nadir Tepesi has a long sequence of occupation dating to the Early Bronze Age, comprised of more than $8 \mathrm{~m}$ of Kura-Araxes

\footnotetext{
Hessari and Akbari 1384/2006.

Alizadeh 2007b.

8 Alizadeh 2007a.
}

Culture deposits, and these are overlain by deposits dating to the twentieth century.

Prior to carrying out the survey, Sasanian period sites and landscape features on the Mughan Steppe were identified using CORONA satellite photographs and aerial images, and these were subsequently visited on the ground. It is notable that several large Sasanian settlement complexes were easily recognisable in a range of CORONA images, and analysis showed that similar settlements are present both within Iranian Mughan and in the areas to the north in the Republic of Azerbaijan. Nine of these fortified sites in Iranian Mughan were visited during the survey (Fig. 2). Ultan Qalas1 appears to have been the largest of these fortified complexes. Another large site known as Ören Kala (ancient Baylaqān), ${ }^{9}$ lies to the north-west of Ultan Qalası, beyond the Iranian-Azerbaijani frontier (Fig. 2). The other fortified sites are rarely more than $100 \times$ $100 \mathrm{~m}$ in size. In most cases, these fortified sites had adjacent extramural areas, but most of these have been ploughed and levelled during the twentieth century $\mathrm{AD}$, which makes it difficult to determine their internal

9 Ahmadov 1997. 


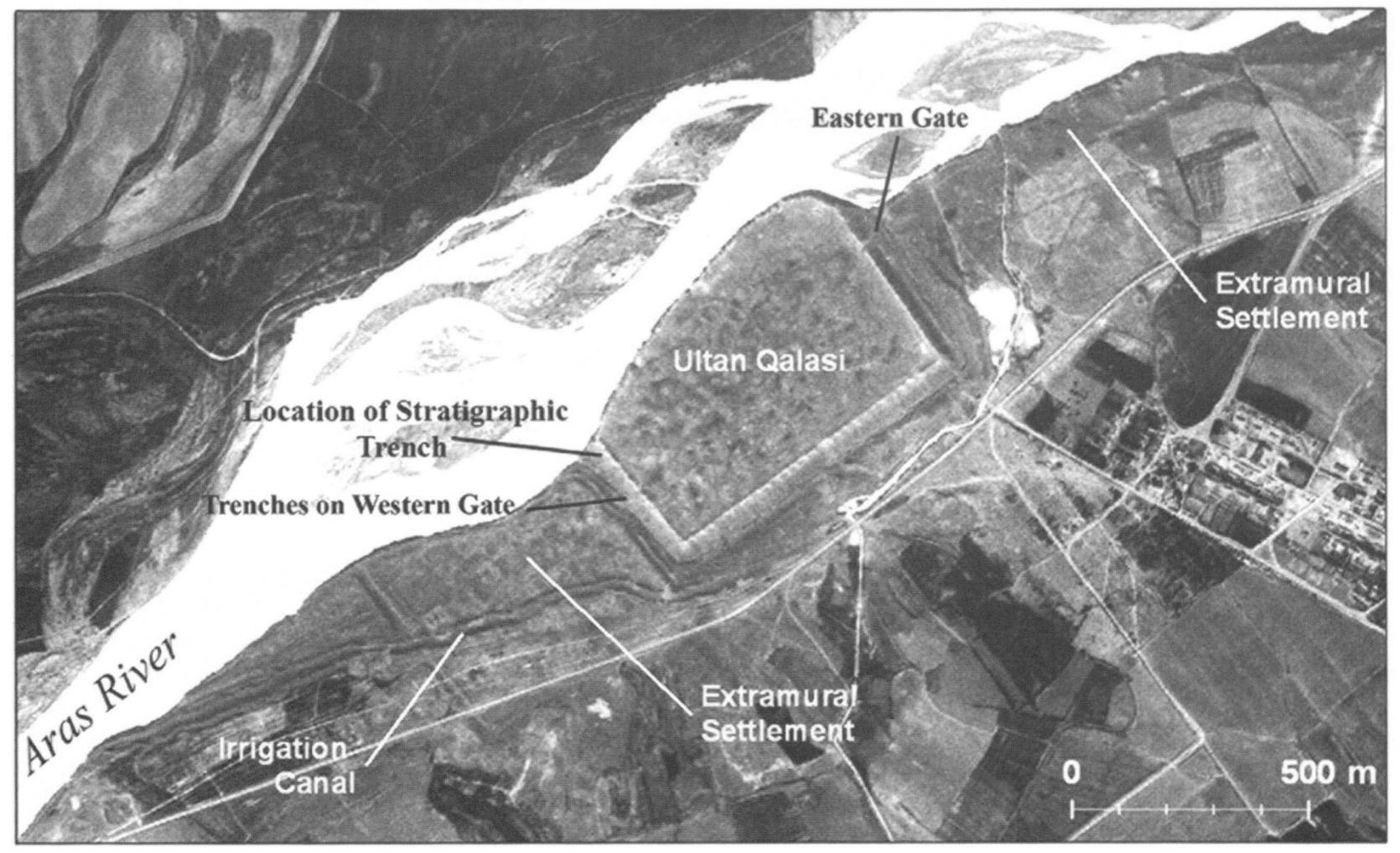

Fig. 3. Satellite image of Ultan Qalasi (CORONA 1110-1154DA065, 30 May 1970).

structure through sherd distribution or topography. The ceramic collections from the surfaces of these sites do, however, have parallels in the ceramic forms found in the first phase of the stratigraphic sounding at Ultan Qalası, which has been dated to the Sasanian period (fifth and sixth centuries $\mathrm{AD}$, see below). It is also notable that these Sasanian settlement complexes were in close association with the remains of irrigation canals. The survey recovered traces of a long branching network of feeder canals stemming from the Aras River to the east of Aslanduz, and these also have evidence for links to dendritic systems from the secondary off-takes (Fig. 2). ${ }^{10}$

The distinctive glazed ceramics that have been recovered from the Early Islamic levels excavated at Ultan Qalas1 (Phase 2; see below) were oddly lacking from the surface collections made throughout the region, indicating that the region may well have been sparsely settled after the Sasanian period. There were, however, hints of earlier occupations (Parthian and Achaemenid periods) at some sites; hence it would

10 See Alizadeh and Ur 2007; Ur and Alizadeh in press. be premature to rule out the existence of pre-Sasanian occupation at any of these sites until we have a complete ceramic sequence from the steppe and a typology of diagnostic types from all periods.

Based on results from our survey project and the excavations at Nadir Tepesi and Ultan Qalası, it appears that with the exception of the Sasanian period, pastoral/nomadism was the main subsistence strategy in the region from the end of the Early Bronze Age up until mid-twentieth century. Furthermore, on the basis of the identification of sites in the satellite and aerial imagery and the truthing of those sites on the ground, it appears as though there is clear evidence for a Sasanian period state-directed settlement system, which incorporated fortified settlements, adjacent extramural zones and canals that cross the steppe (Fig. 2). ${ }^{11}$

11 See Alizadeh and Ur 2006; 2007; Mohammadi 2004. The Mughan Steppe experienced agricultural intensification in the form of a massive irrigation system with the modern development programme directed by the last king of Iran under the name of the "White Revolution". See Pahlavi $1345 / 1966$. 


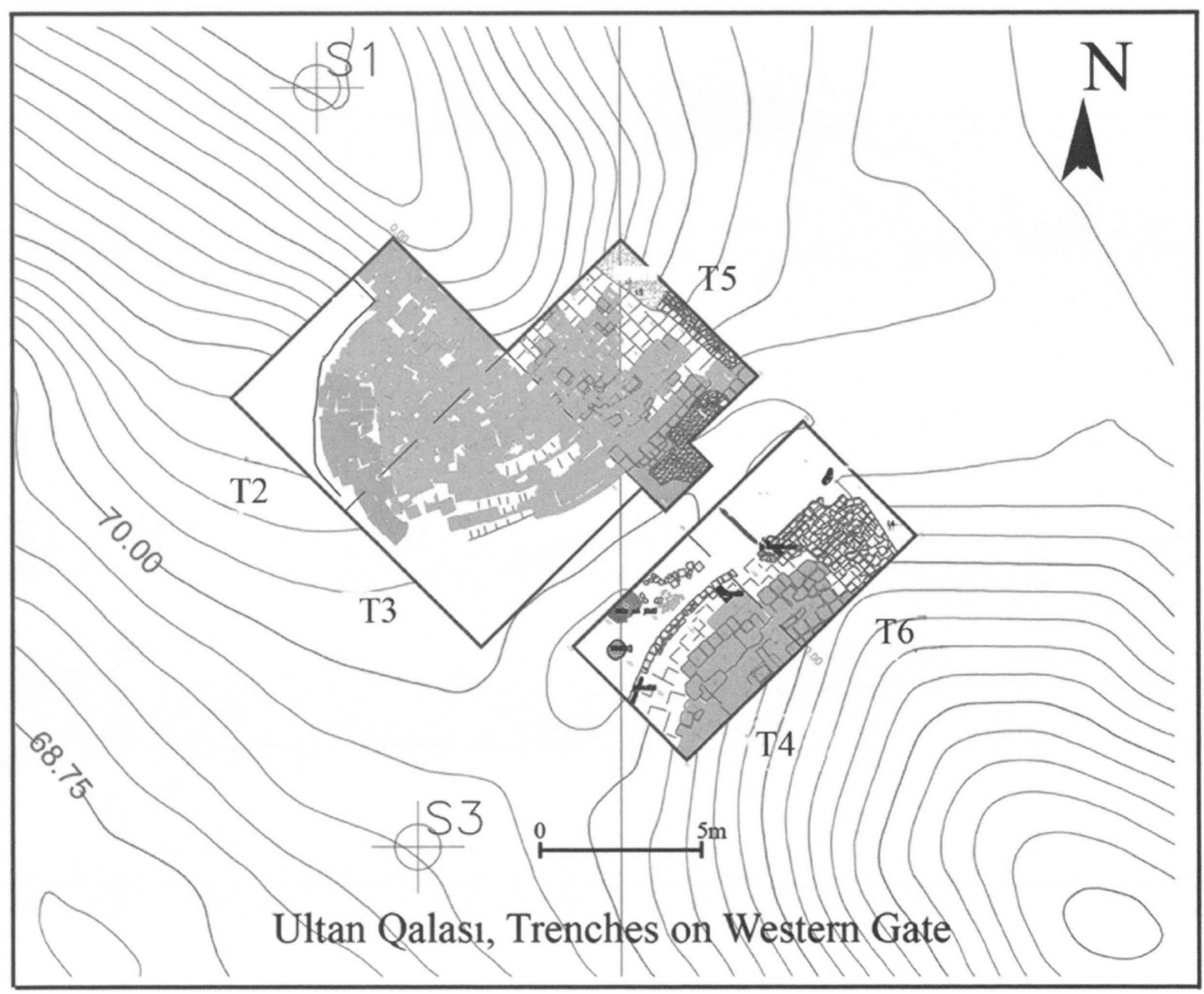

Fig. 4. Trenches 2, 3, 4, 5 and 6, placed in order to investigate the Western Gate.

\section{ULTAN QALASI}

The largest settlement complex on the Mughan Steppe is the site of Ultan Qalas1, which is perched on the south bank of Aras River (Fig. 3), immediately west of Ultan village and between Parsabad and Aslandouz towns in Ardabil province (Fig. 2). The roughly square-shaped fortified site has been known since the early nineteenth century, ${ }^{12}$ and today, its south-eastern side is $720 \mathrm{~m}$ in length, its north-eastern side is about $504 \mathrm{~m}$, and its south-western side is about $320 \mathrm{~m}$. Ultan's builders appear to have used the curving riverterrace edge to define the settlement's north-western

12 E.g. Monteith 1833: 29-30. Based on Monteith's account, the site in the nineteenth centrury was called Altun Tukht or Takht (the Golden Throne). side, which extends for $745 \mathrm{~m}$. Although a defence mechanism relying on the natural defences offered by a river terrace was used in the city of Bishapur, ${ }^{13}$ it is also possible that some of the northern parts of Ultan Qalas1 have been washed away by the Aras River. None of corners of the fortification are precisely rightangled, but each points to one of the cardinal directions. Analysis of satellite images and observations on the surface suggest that there were numerous towers along the walls, and two of these have been exposed during targetted excavations. Surface observations also identified a discontinuity in the western wall, and excavations in this area have revealed a gate with semi-circular mud-brick towers on each side (Trench 9; Fig. 4).

13 Karimian 2010: 460. 


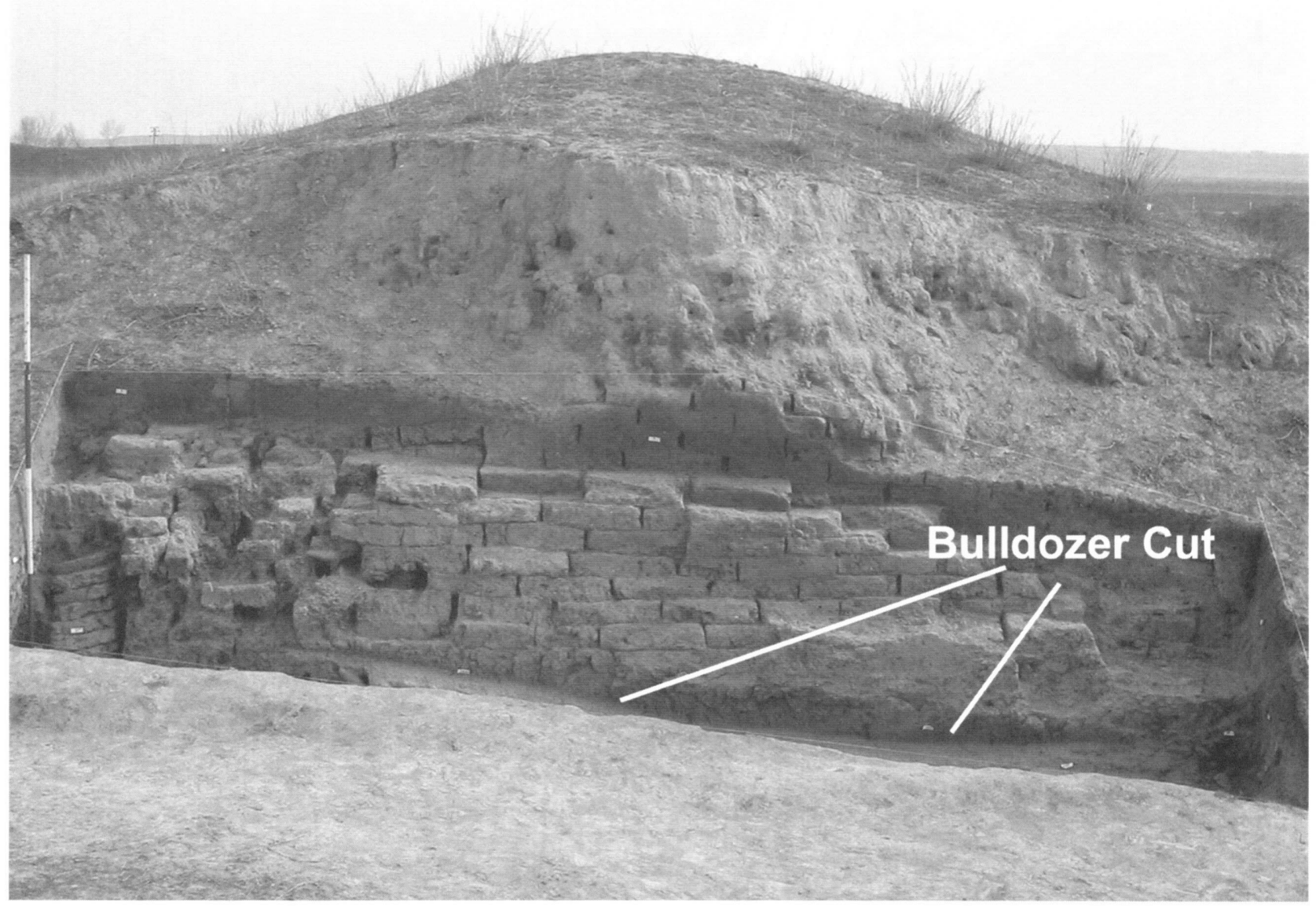

Fig. 5. Trench 1 for stratigraphy.

There is evidence in the CORONA imagery of extramural settlement south-west, south and east of this citadel (Fig. 3). ${ }^{14}$ Interestingly, the extramural area in the south-west of the citadel, on the terrace edge, is divided into several sectors by a network of ancient canals. The fortified part of the site, or the Citadel, is about 33 ha in size, but when the citadel and extramural area (Rabad/exterior part of city) are taken together, the site covers more than 70 ha. The extramural areas to the south were badly damaged in 1951 by an intensive irrigation scheme (Fig. 2), and more recently, gravel extraction has disturbed the western suburban area that is visible in CORONA photographs.

One of the canals that cut through the extramural areas goes around the Citadel to form a moat, before flowing back into the Aras River. Traces of other canals

14 Alizadeh and Ur 2006; 2007. joining the moat suggest that there was once a network of canals and subsidiaries either for irrigation or supplying water to the Ultan. During recent decades, the moat at the south-west side of the Citadel has been reused as part of the sewer system of a sugar factory up in the south of the steppe and a new modern canal has been constructed at that area of the site. In size and settlement morphology, Ultan Qalası is very similar to its contemporary fortress at Ören Qala (ancient Beylaqan), which also lay on a long canal coming from the Aras. ${ }^{15}$

\section{IV.1. Excavations}

Excavations at Ultan Qalas1 were prioritised due to the threat of damage and destruction by modern development in the area and the action of the Aras River. The

15 See Ahmadov 1997. 


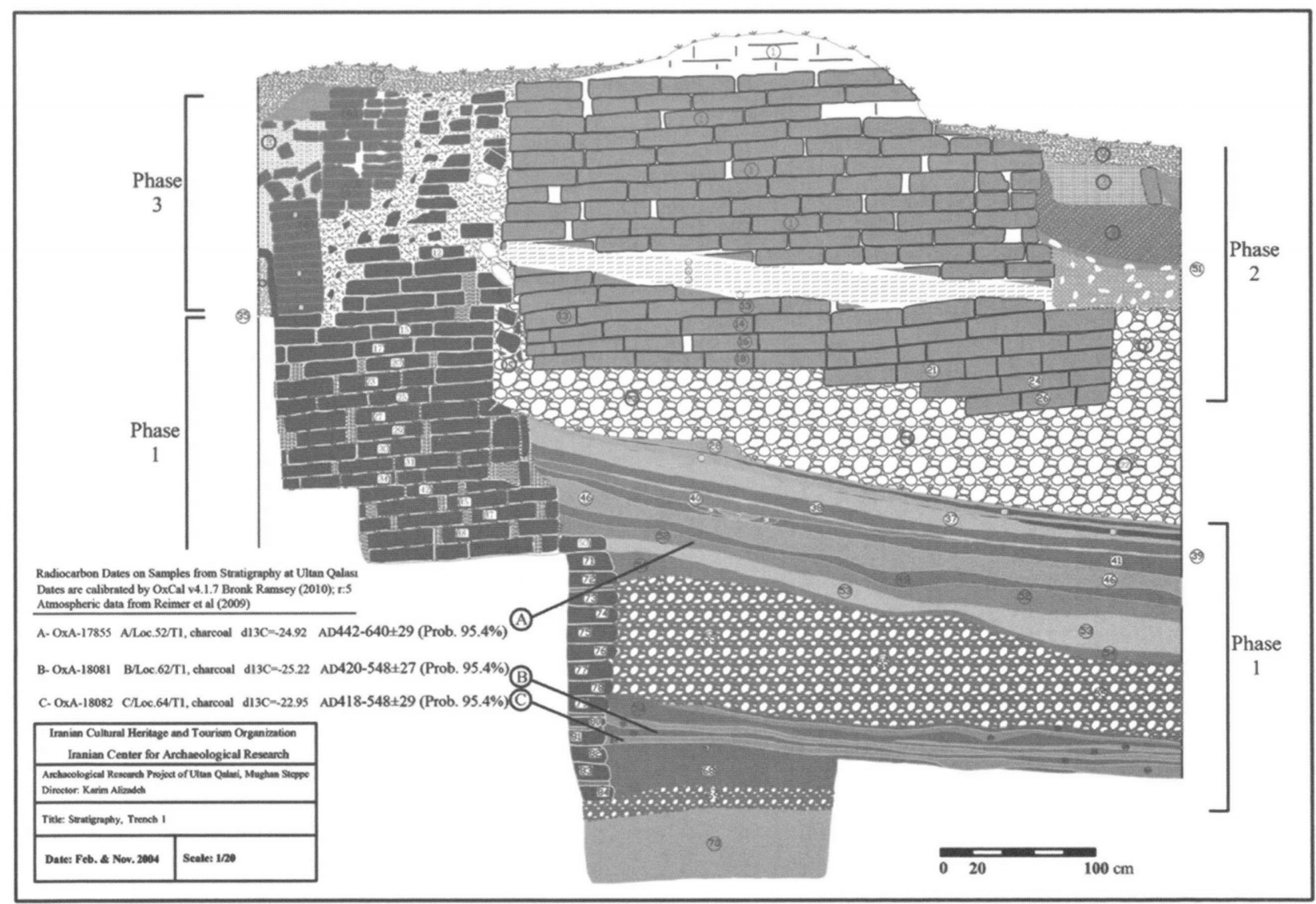

Fig. 6. Stratigraphy at Ultan Qalası, Trench 1 (Alizadeh 2007b).

excavations that were carried out under the aegis of the Mughan Steppe Archaeological Project took place with the initial aims of establishing the periods of occupations of the site and investigating the gate(s) of the citadel. ${ }^{16}$ In order to understand the site's stratigraphy and to build a chronological sequence of its occupation, one modest sized $(2 \times 6 \mathrm{~m})$ test trench $($ Trench 1) was excavated (Fig. 5), and the preliminary results of this will be outlined here.

Trench 1 was placed on top of a section cut through the south-western fortifications of the citadel by a bulldozer (Fig. 5). The trench is located at E $47^{\circ} 45^{\prime} 15^{\prime \prime}$, $\mathrm{N} 39^{\circ} 36^{\prime} 24^{\prime \prime}$, and at a height of $73 \mathrm{~m}$ above sea level, and is close to the western corner of the Citadel (A). ${ }^{17}$ The trench was excavated to a depth of more than $5 \mathrm{~m}$ to virgin soil and contained materials from the earliest phases of the site (Figs. 6-7).

\footnotetext{
16 See Alizadeh 2006/1385.

17 See Alizadeh 2007b: 17-18.
}

There were four major phases revealed in Trench 1, and these have been numbered 1 to 4 , from bottom to top. Phase 1 is comprised of the dark brown mud-brick wall of the earliest fortification and related layers, while Phase 2 comprised the upper/new fortifications (Fig. 7). Phase 3 consisted of structures built inside the Phase 2 mud-brick wall (Fig. 8), and Phase 4 was comprised of surface deposits.

The Phase 1 wall was preserved to nearly a height of $5 \mathrm{~m}$, and the bricks were all broadly similar in size, with dimensions of between $38 \times 38 \times 10 \mathrm{~cm}$ and $43 \times$ $43 \times 10 \mathrm{~cm}$, with some bricks being $40 \times 32 \times 10 \mathrm{~cm}$. During its earliest phase of occupation, there is evidence that Ultan Qalası's inhabitants encountered two major floods of the Aras River (Fig. 9). The Phase 2 wall was made of bricks of similar though slightly smaller dimensions, ranging from $25 \times 25 \times 10 \mathrm{~cm}$ to $38 \times 38 \times 8 \mathrm{~cm}$. The mud-brick fortifications of Phase 2 were constructed atop the deposits of the second 


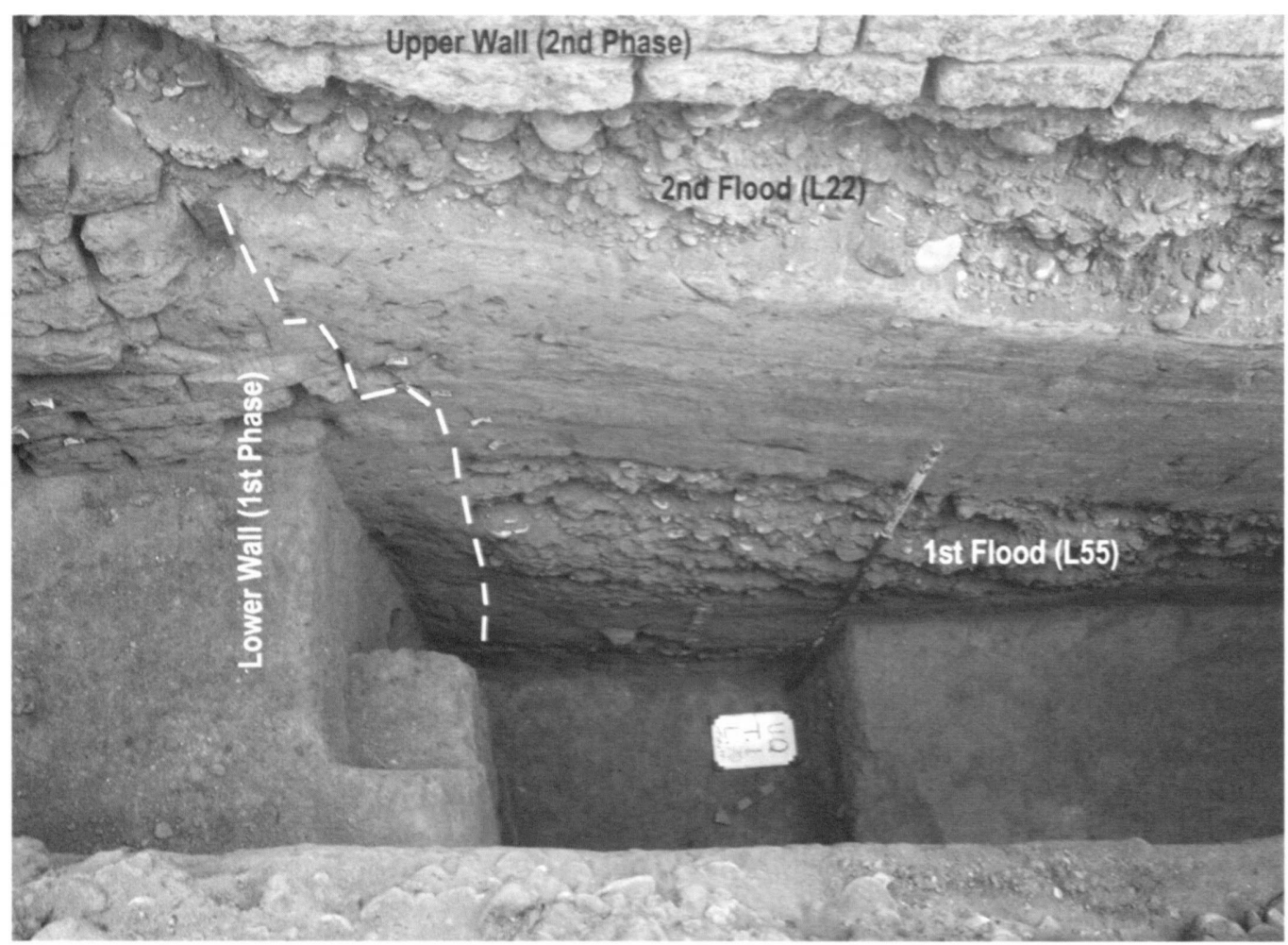

Fig. 7. Citadel walls and flood deposits.

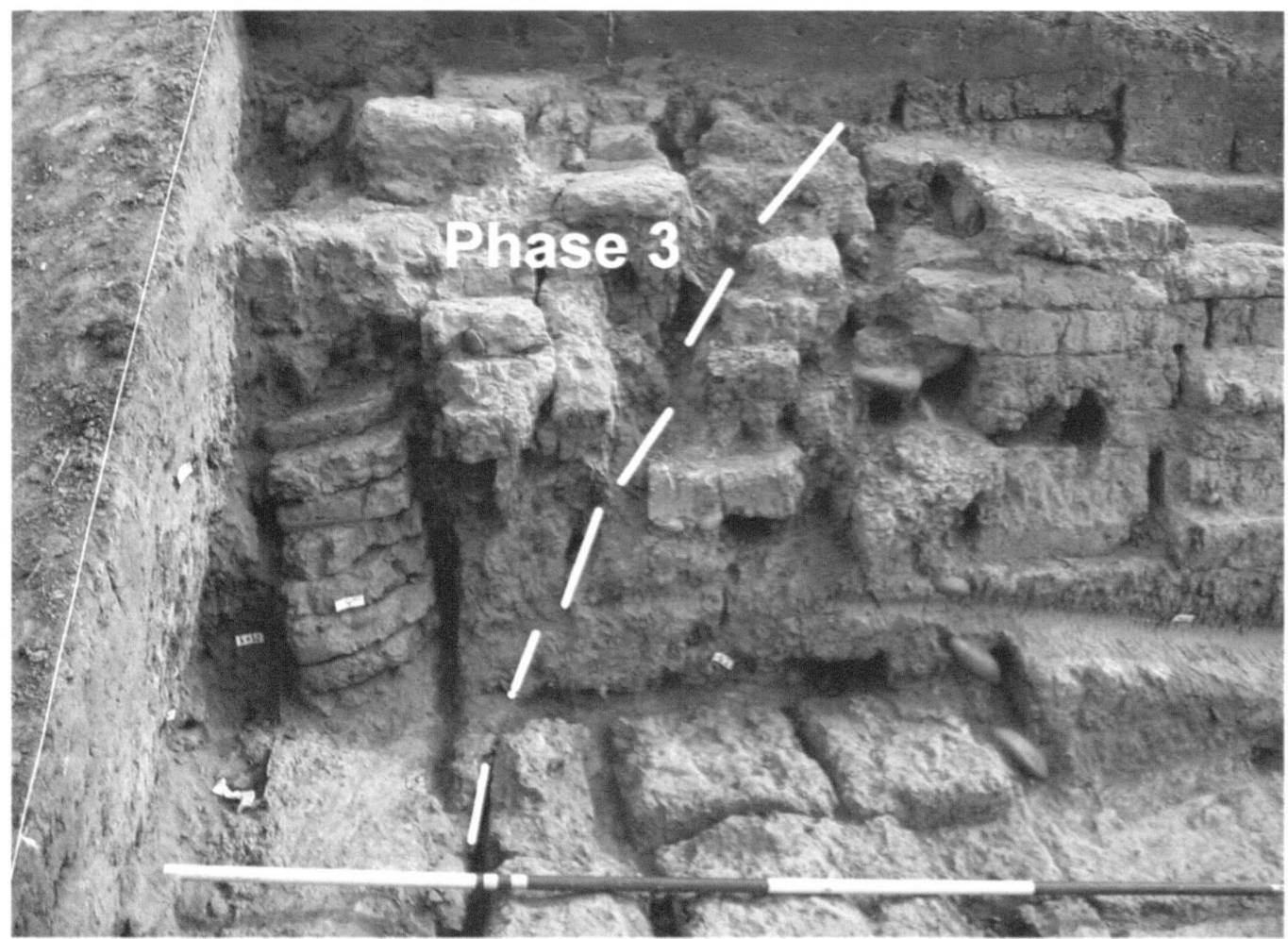

Fig. 8. Phase 3 Structures on lower wall (Phase I) 


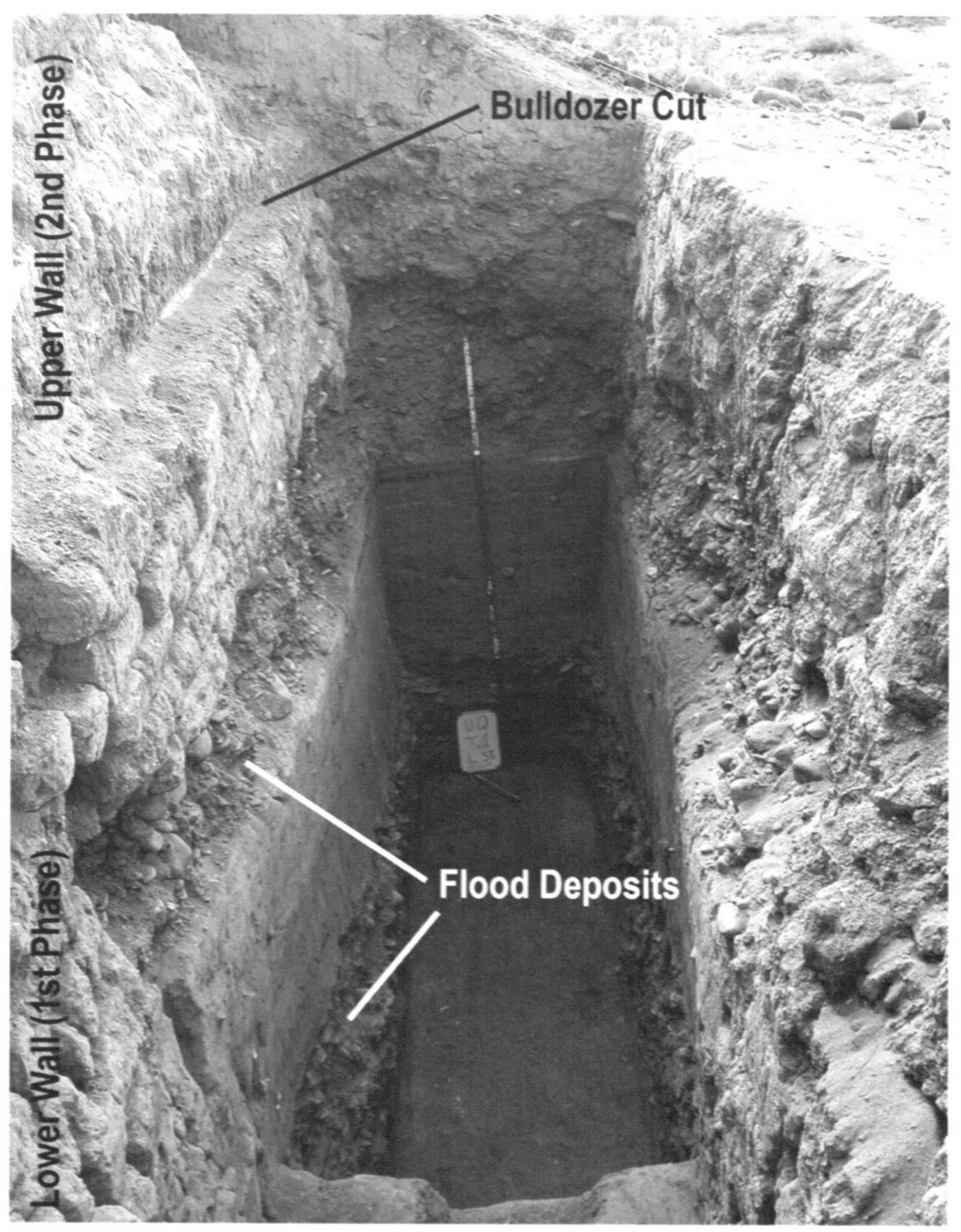

Fig. 9. Citadel walls and two flood deposits.

flood event. In Phase 3, an enigmatic small construction was built atop the interior face of the lower (Phase 1) fortifications (see Fig. 6).

\section{IV.2. Ceramics}

The ceramic collection from Trench 1 was relatively small, and due to the limited size of the sounding, it cannot be assumed that the pottery assemblages recov- ered from each phase are truly representative of the range of vessels that were being used during any one chronological period. Nevertheless, the ceramic material that was recovered provides a basis for attributing the known stratigraphic phases to specific chronological periods. A total of 450 sherds were collected from Trench 1. Because the upper part of the second wall was destroyed by the bulldozer cut and its associated layers were disturbed and mixed with top soil materials, the ceramics found below loci $12-15$ have been 

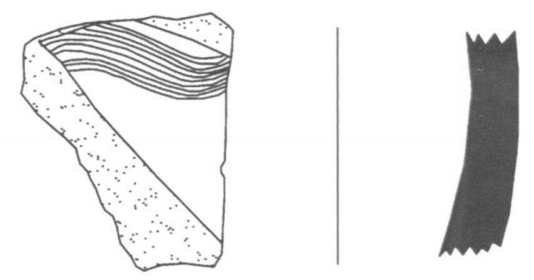

T1.L62.7
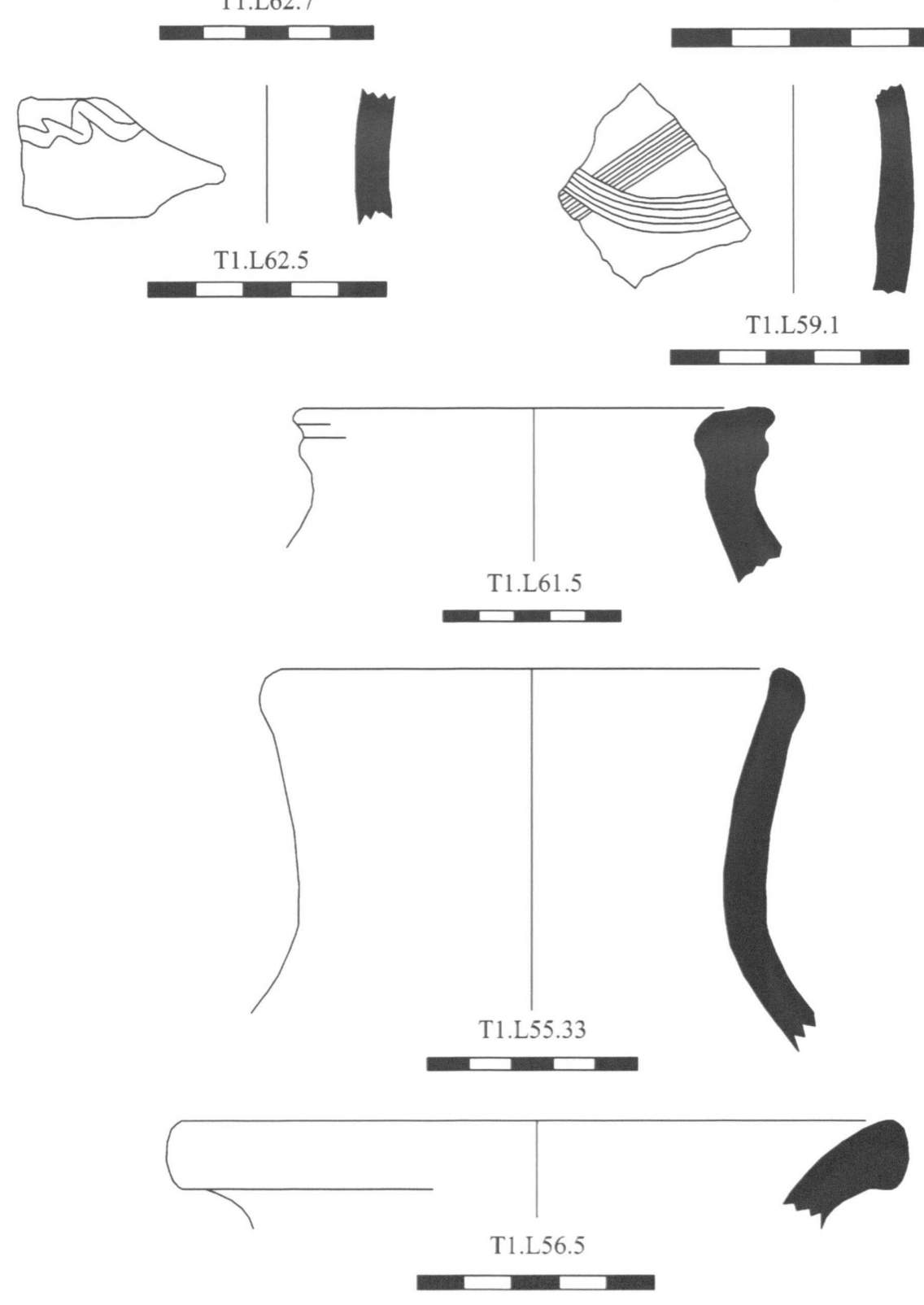

Fig. 10. Ceramics from Phase 1 (after Alizadeh 2007b). 


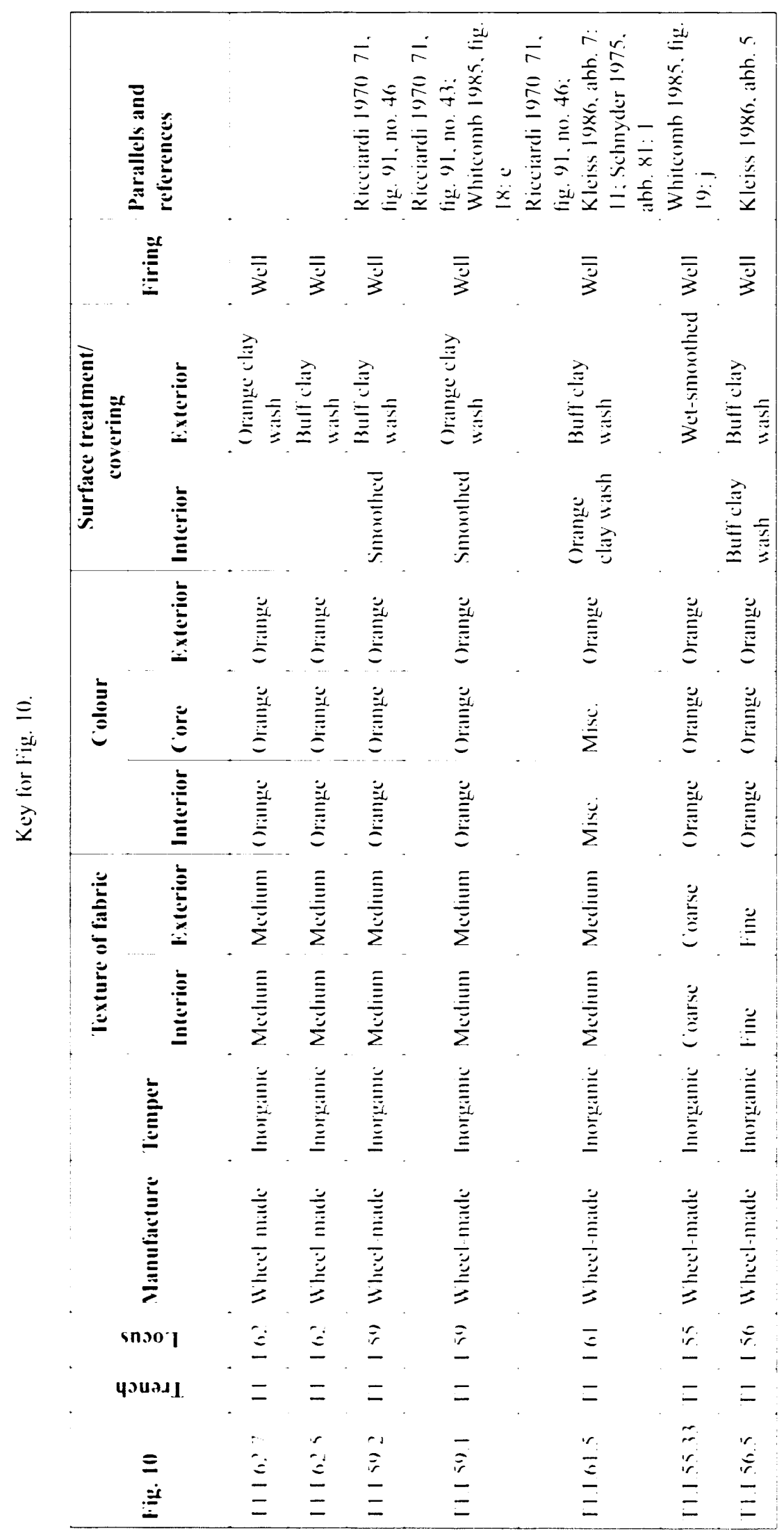




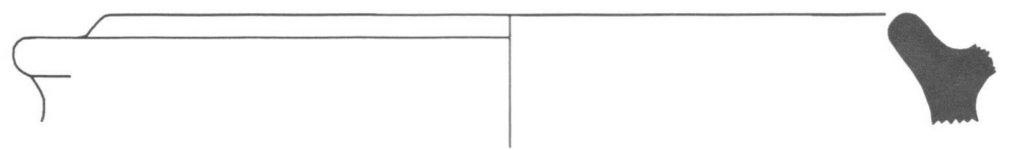

T1.L54.24

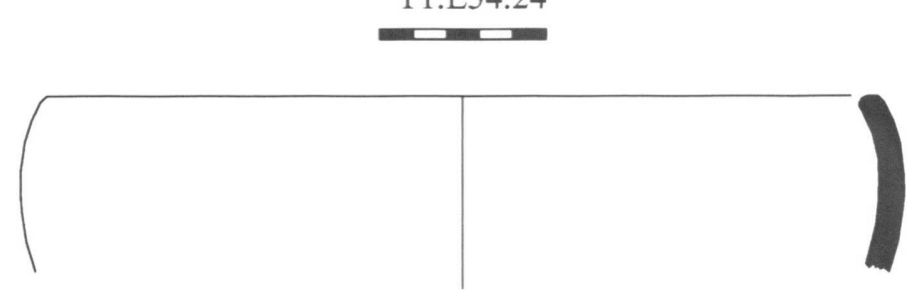

T1.L55.4

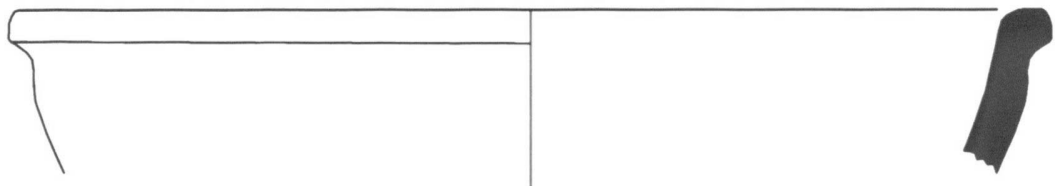

T1.L55.3
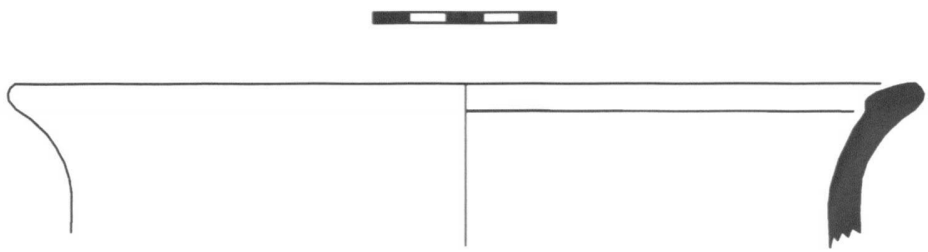

T1.L54.7

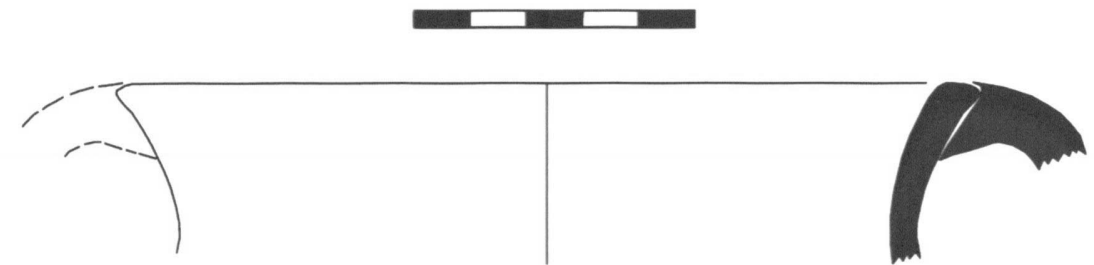

T1.L54.11

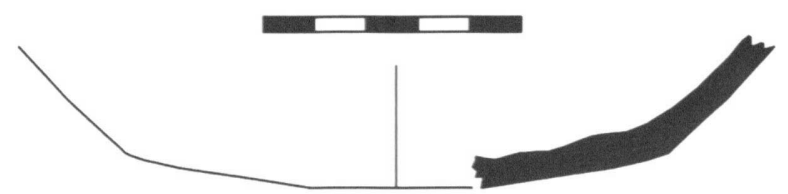

T1.L52.2

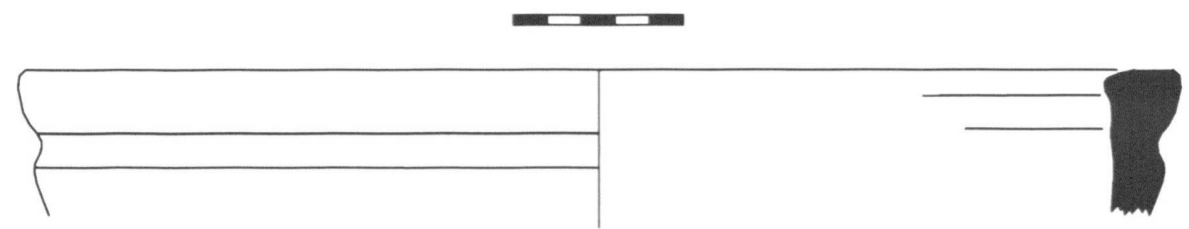

T1.L46.8

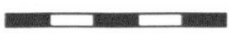

Fig. 11. Ceramics from Phase 1 (after Alizadeh 2007b). 


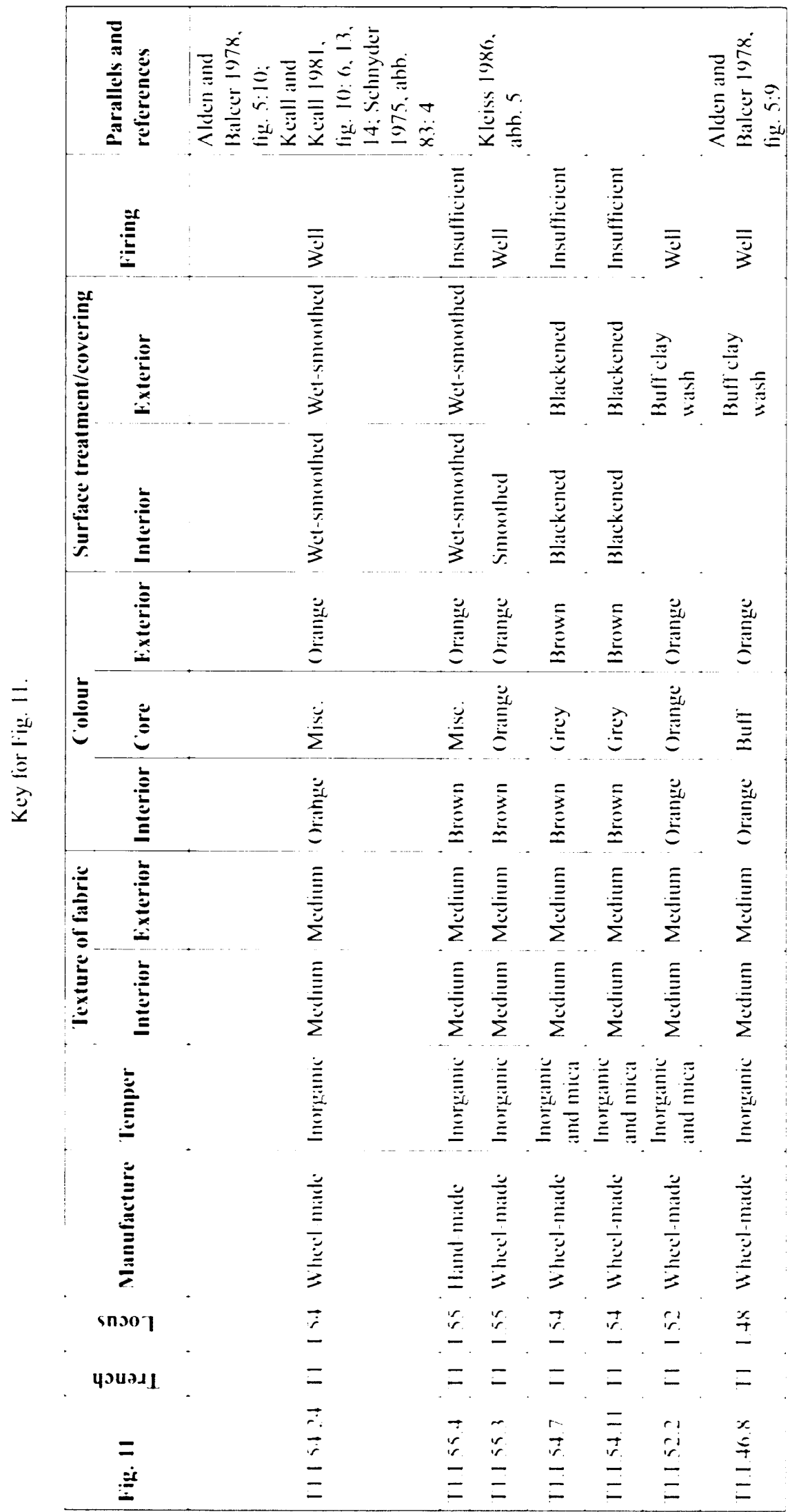




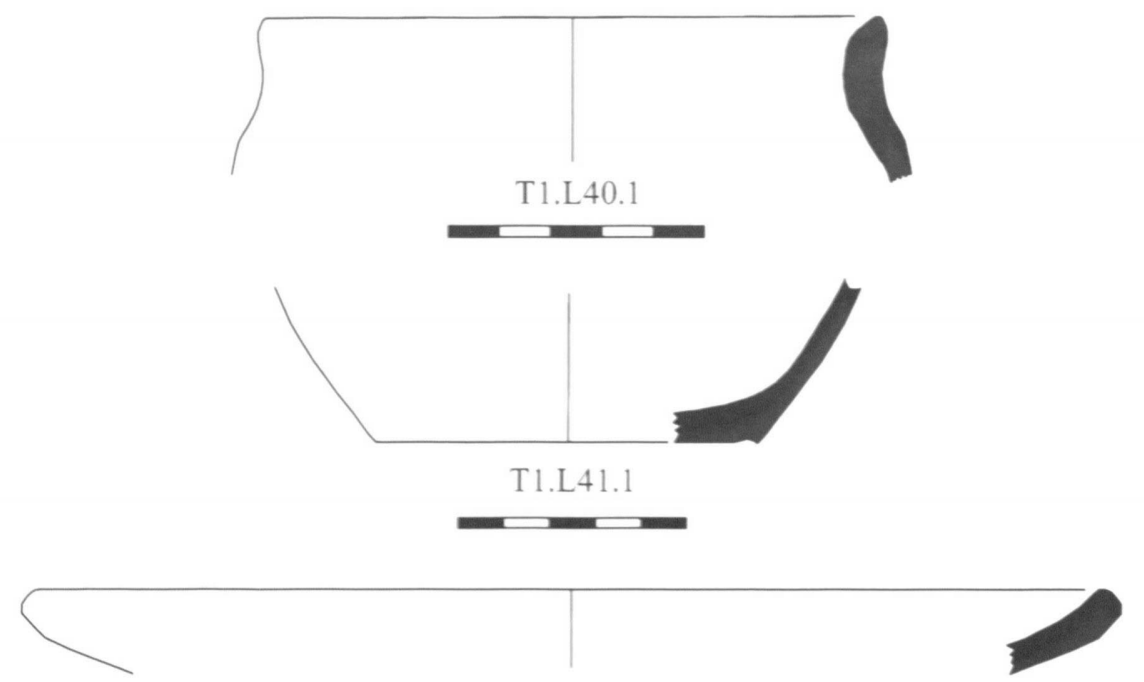

T1.L46.2
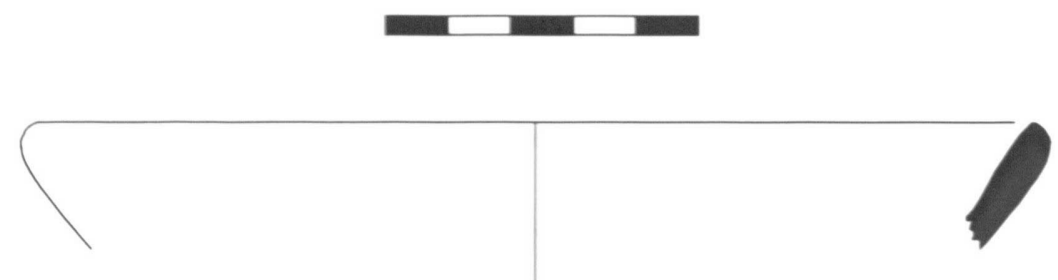

T1.L28.2
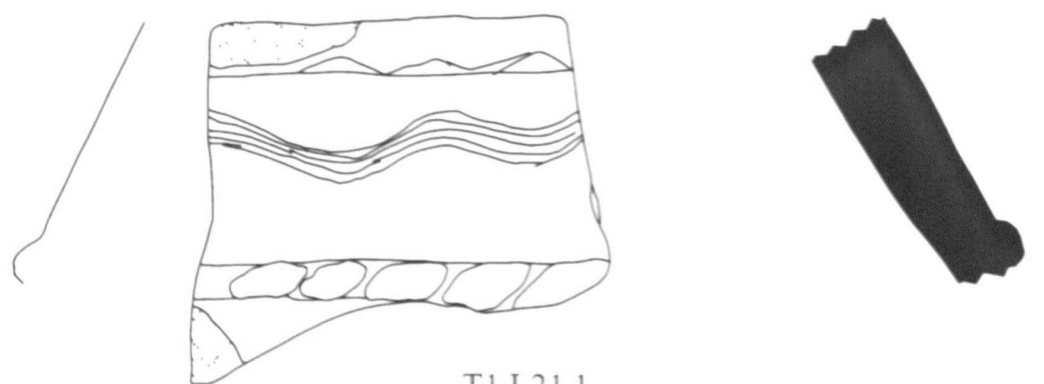

T1.L21.1
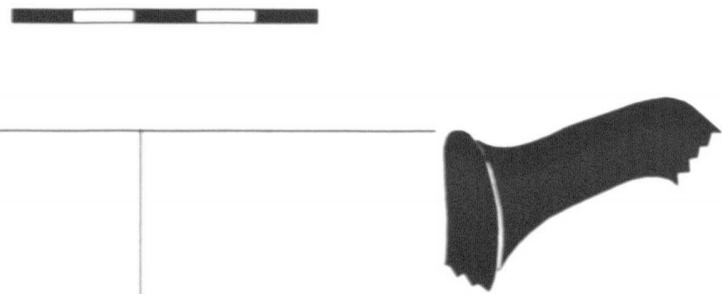

T1.L18.1
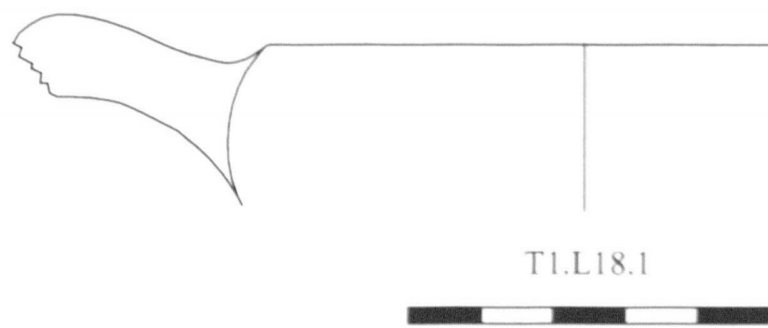

Fig. 12. Ceramics from Phases 1 and 2 (after Alizadeh 2007b). 


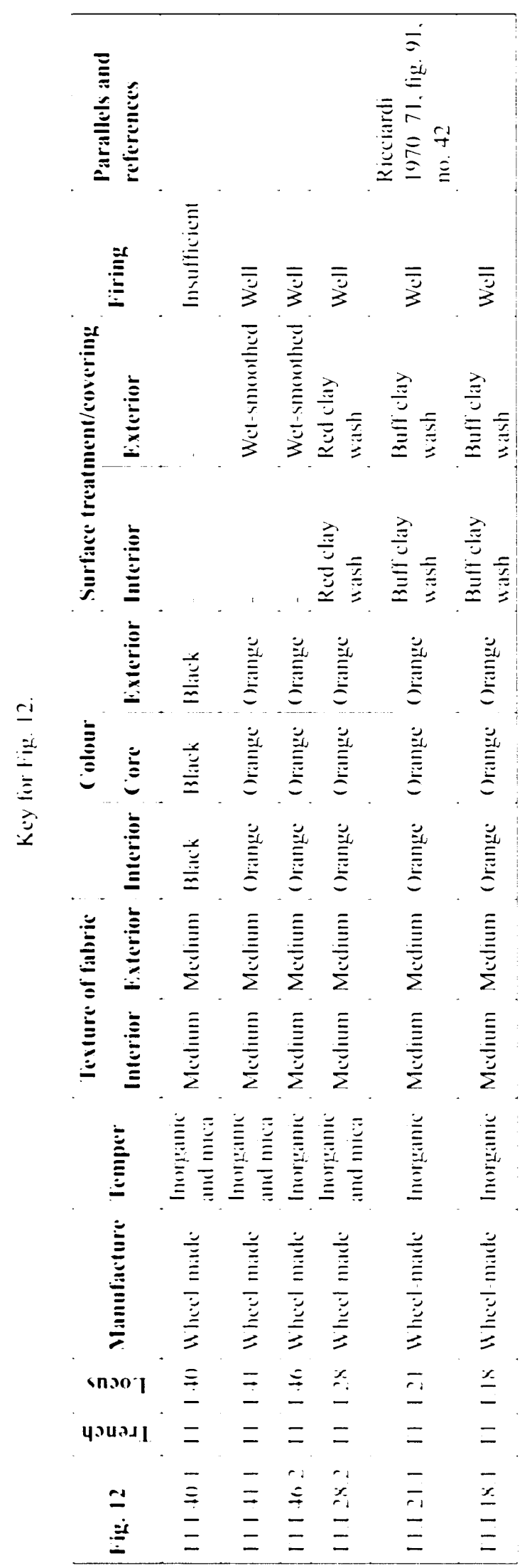



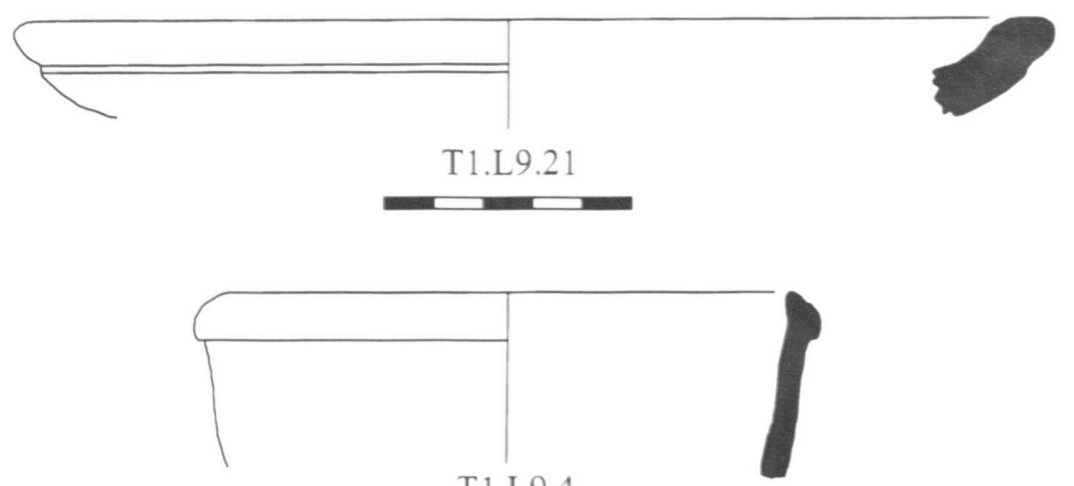

T1.L9.4

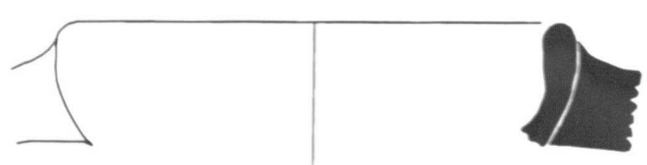

T1.L9.22

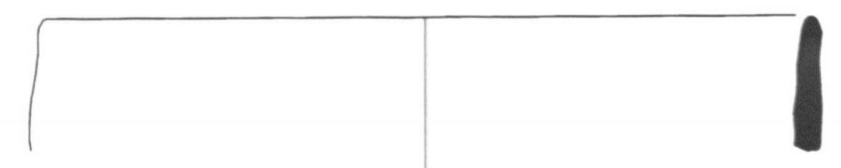

T1.L9.18

त्व

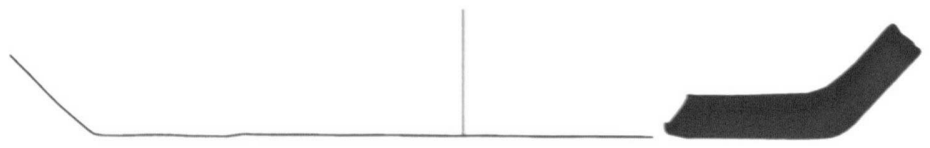

T1.L9.16
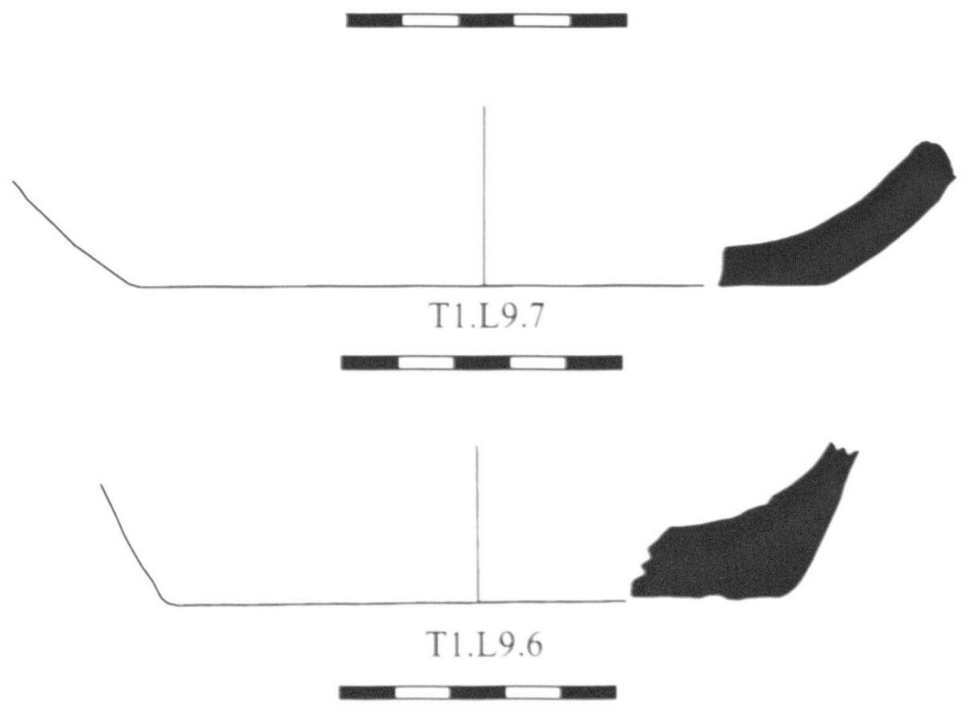

Fig. 13. Ceramics from Phase 2 (after Alizadeh 2007b) 

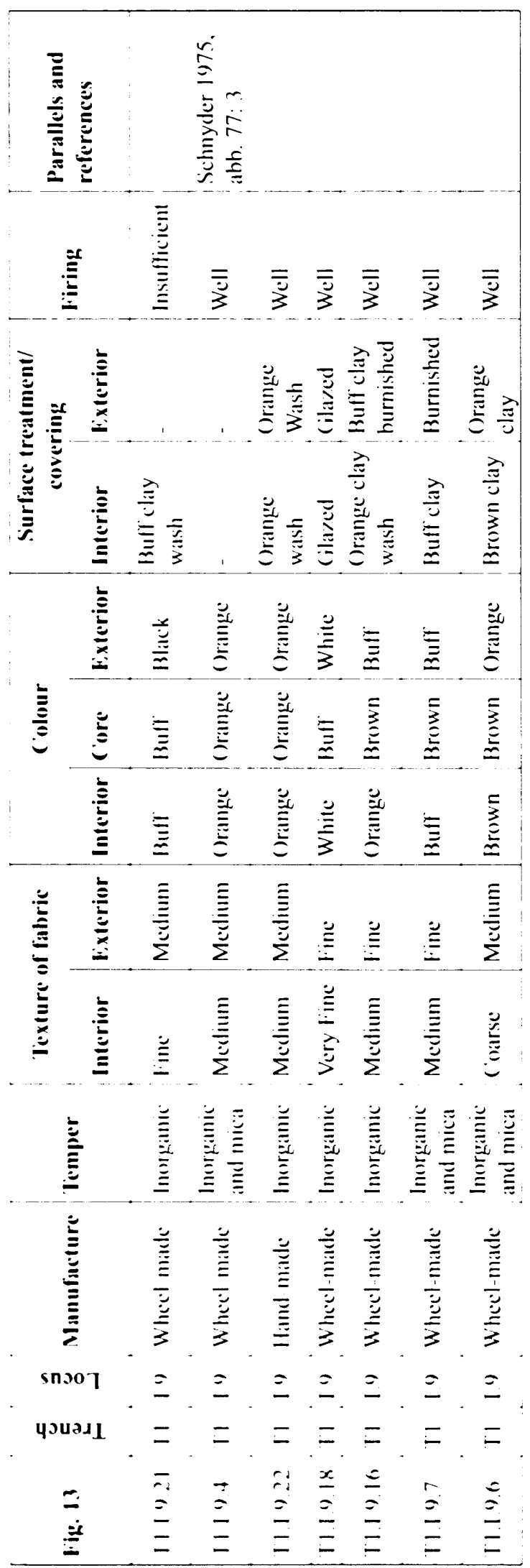
TABLE 1. Radiocarbon determinations from Ultan Qalas1. Calibrated using OxCal v4.1.7 Bronk Ramsey (2007); r:5. Atmosphere data from Reimer et al. (2009).

\begin{tabular}{|c|c|c|c|c|}
\hline \multirow{2}{*}{ Sample no. } & \multirow{2}{*}{$\begin{array}{l}\text { Radiocarbon } \\
\text { age (BP) }\end{array}$} & \multirow{2}{*}{ Error } & \multicolumn{2}{|c|}{ Calibrated age } \\
\hline & & & $68.2 \%$ probability & 95.4\% probability \\
\hline OxA-18082 & 1576 & 29 & $\begin{array}{l}\text { AD } 434-70(28.0 \%) \\
\text { AD } 480-97(13.8 \%) \\
\text { AD } 502-35(26.4 \%)\end{array}$ & AD $418-548(95.4 \%)$ \\
\hline OxA-18081 & 1574 & 27 & $\begin{array}{l}\text { AD } 434-93(47.0 \%) \\
\text { AD } 506-35(21.2 \%)\end{array}$ & AD $420-548(95.4 \%)$ \\
\hline OxA-17855 & 1497 & 29 & AD $546-600(68.2 \%)$ & $\begin{array}{l}\text { AD 442-51 }(1.0 \%) \\
\text { AD 462-84 (3.2\%) } \\
\text { AD 532-640 (91.2\%) }\end{array}$ \\
\hline OxA-18083 & 1214 & 27 & AD $774-870(68.2 \%)$ & $\begin{array}{l}\text { AD } 694-98(0.4 \%) \\
\text { AD } 708-47(11.9 \%) \\
\text { AD } 766-889(83.1 \%)\end{array}$ \\
\hline
\end{tabular}

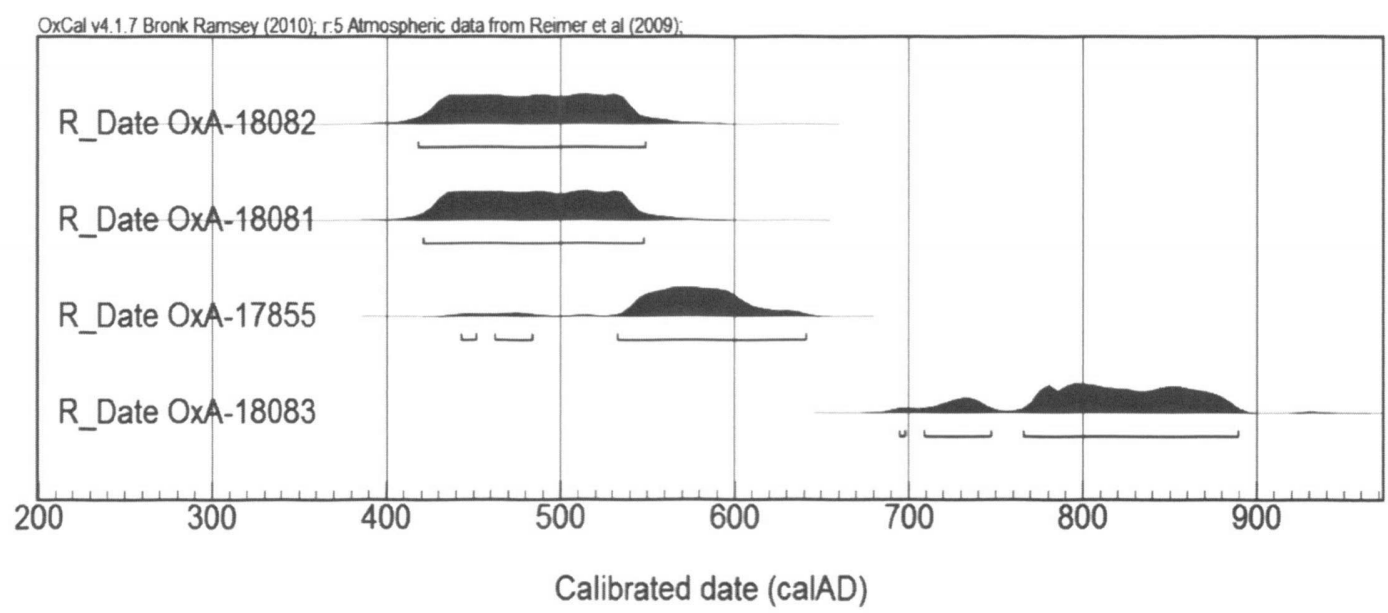

Fig. 14. Age distribution of radiocarbon samples analysed from Ultan Qalasi.

used here for relative dating. A selection of this material is illustrated in Figures 10-13.

Phase 1 wares are mostly wheel-made, grittempered, and well fired. The great majority of them have mica in the paste. Paste colour varies from a predominant orange, with rare buff, grey and light brown. Commonly their exterior and interior surfaces are slipped, with a fine/medium surface finish. The most common shapes are jars (Fig. 13; T1.L46.8, T1.L54.7, T1.L54.11, T1.L54.24). Open-mouthed forms were represented by the presence of bowls and a jug (Fig. 12; T1.L55.33). Double-rimmed vessels (Fig. 13; T1.L54.24) are comparable with examples from Sasanian contexts at Susa ${ }^{18}$ and the Sasanian ceramics

18 Miroschedji 1987. of Tal-i Malyan, ${ }^{19}$ Qal'eh-i Yazdigird 20 and Takht-i Suleiman. ${ }^{21}$ Two types of decoration were used on the ceramic vessels: relief and incised decoration.

\section{IV.3. Chronology}

The limited ceramic assemblages and recently obtained radiocarbon dates from Trench 1 attest to occupation of the site in the Sasanian period. Phase 1 appears to date from the early decades of fifth century (OxA-18082, AD 418-548 and OxA-18081, AD $420-548$ at $95.4 \%$ probability), while Phase 2

19 See Alden and Balcer 1978, fig. 5: 10.

20 See Keall and Keall 1981, fig. 10: 6, 13, 14.

21 See Schnyder 1975, abb. 83: 4. 
appears to date to the late Sasanian/Early Islamic period (OxA-18083, AD 694-889)22 (see calibrated dates in Fig. 14 and Table 1). Phase 2 as identified in Trench 1 will be better studied through investigating the evidence from Trench 9, which revealed the gate/ entrance of the citadel described above (Fig. 4). ${ }^{23}$ The radiocarbon date for Phase 2 from Trench 1 has, however, been supported by numismatic evidence. After lab analysis for cleaning patinas, a copper coin which was found in Trench 9 next to the left tower of the western gate (in a level of fill and not exactly on the floor), was shown to be adorned with Kufic Arabic writing in three lines saying "la ilaha illalah, wahdahu la sharika lah"24 (see Fig. 15). On the basis of inscription typology, and considering the historical context for the appearance of this type of phrase on coins, it suggests a date around the first-second centuries of the Islamic period (AD seventh-eighth centuries). ${ }^{25}$ The chronology of the third phase is not clear because of a lack of stratified cultural material. However, based on some ceramic types and their parallels, it is likely to date to the Seljuq period.

The earliest phase at Ultan Qalası (Phase 1) has thus far only been exposed in Trench 1, and the nature of the earliest occupation in other areas of the site remains unknown. The surviving height of the early wall (more than $5 \mathrm{~m}$ ) and the dates from the associated floor levels indicate that this substantial first phase should be dated to the mid-fifth century AD. The fact that this earliest fort encountered two big floods of Aras River during its life indicates that the Aras River bed may well have been higher than it is at present, and establishing when the Aras River started to downcut into its present channel would provide insight into both the development of the site and the transformation of the Mughan Steppe's landscape.

22 Dates are calibrated by OxCal v4.1.7 Bronk Ramsey (2007); r: 5, Atmospheric data from Reimer et al. (2009).

23 In the third season of excavations, we opened three more trenches (T7, T8 and T9) between earlier T3 and T5 in the western side of the gate and T4 and T6 in the eastern side. These new trenches are not seen in Fig. 4.

24 I should thank Mr Abdollah Qouchani for his kind help in identifying Kufic characters, reading the inscriptions and dating the coin. This was very helpful in our earliest understanding of the chronology of the site, especially before we had the Carbon 14 dates.

25 See Qouchani 1383/2004; Shams Eshraq 1369/1990.
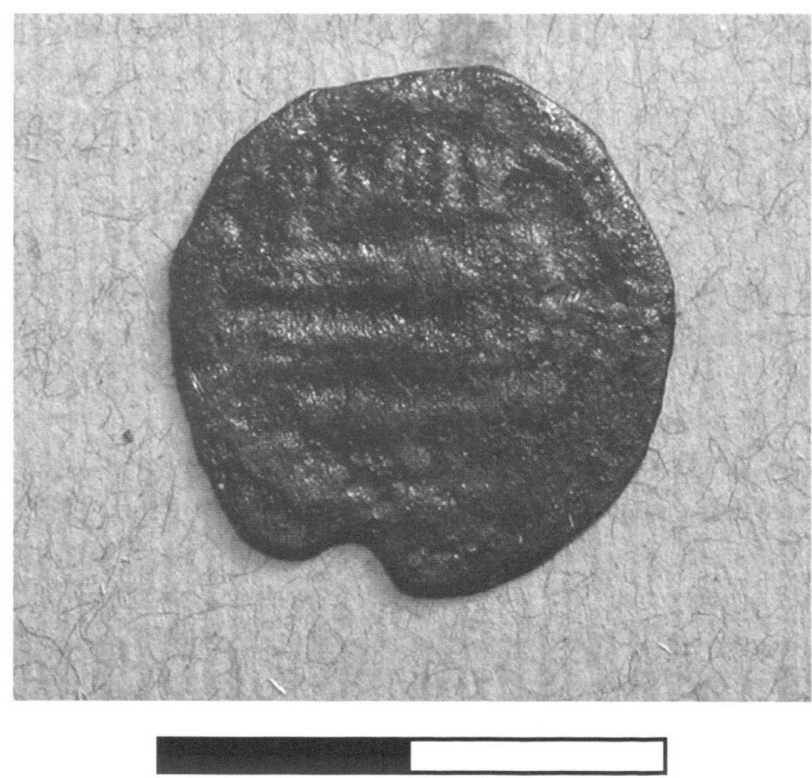

Fig. 15. Copper coin found next to western tower of western gate (Alizadeh 2007b).

\section{DISCUSSION AND CONCLUSIONS}

Epigraphic documentation for historic period settlement in Mughan is rather sparse. But the archaeological investigations in the western Mughan Steppe 26 in Iran and the eastern Mughan and Mil Steppe regions in Azerbaijan 27 indicate that there are many Sasanian sites, which are mostly fortified and lie along ancient canals. While the sites of Ultan Qalası and Ören Kala are particularly large, most of the other sites have modest fortified components that are rarely as much as $100 \times 100 \mathrm{~m}$ in size, and some are closer to a quarter of that.

In the Sasanian division of the world into "Iran" and "Non-Iran", Balasagan (most likely the ancient designation for the Mughan Steppe) and the lands of the southern Caucasus were considered to be nonIranian or anérān. ${ }^{28}$ Balasagan was a generally stable vassal kingdom within the Sasanian Empire, but was occasionally caught up in intrigues between Albania, Armenia and the Sasanian state. ${ }^{29}$ Sasanians in this area and the Caucasus can be studied through both written sources such as Shapuhr I's Ka'be-ye Zard-

\footnotetext{
6 See Alizadeh 2007b; Alizadeh and Ur 2007.

27 Ahmadov 1997.

28 Frye 1963: 206; Gignoux 1986; Marquart 1931.
}

29 Chaumont 1985; 1989. 
osht (Naqsh-e Rustam in southern Iran) inscriptions ${ }^{30}$ and the archaeological evidence found in excavations and surveys of the Derbend fortifications, Baylaqan and the Gilgil Chay Project. ${ }^{31}$ During the later Sasanian period, it appears that the Mughan Steppe and other areas of the Caucasus and Transcaucasia were formally colonised by the Sasanians, who established the fortification and irrigation systems described above. 32

The establishment of Ultan Qalası, with its regular layout, strong fortifications, surrounding moat and network of irrigation canals, and the other fortified centres on the Mughan Steppe, and the construction of an irrigation system to link these settlements, appears to have taken place within a short period of time and thus bears the hallmarks of a state-sponsored project. It is in many ways logical to assume that such massive projects could only be achieved during a period of protracted peace, and this notion has led many scholars to attribute this project to Khusro I (AD 531-79), or Khusro Anushirawan ("of immortal soul"). ${ }^{33}$ However, archaeological investigations in frontier areas such as Darband, Besh Barmaq and Gilgilchay in the Caucasus ${ }^{34}$ and the Gurgan and Tammishe Walls in the north-east of Iran ${ }^{35}$ have shown that kings before Khusro I, including Shapuhr II (AD 309-79) and Yazdigerd II (AD 438-57) were also engaged in securing frontiers through the construction of massive defensive walls, establishing planned cities, and irrigation canal systems for agriculture, and large population movements.

Based on the archaeological evidence and the recently obtained radiocarbon dating results (Table 1), I would argue that the socio-political situation during the reign of Yazdigerd II (AD 438-57) in the middle of the fifth century was suitable for such a construction project. Based on archaeological evidence in the Caucasus at sites such as Darband, Gilgilchay, Besh Barmaq walls, Torpaq Qala (Shahristan-i Yazdigerd), and other Sasanian sites and fortifications in the north-eastern parts of the Sasanian Empire, it appears that Yazdigerd

30 See for instance Lukonin 1983: 730.

31 See Ahmadov 1997; Aliev et al. 2006: Gadjiev 1997: 2008; Gadzhiev and Kasumova 2006; Kettenhofen 1996: Kudriavtsev 1982; 1993.

32 Bosworth 1990: 2.

33 Ahmadov 1997: 21-22; Alizadeh and Ur 2007: 154: Frye 1977: 15.

34 Kudriavtsev 1993, Aliev et al. 2006.

35 Omrani Rekavandi et al. 2008.
II endeavoured to found cities, and construct ditches (khandaq) and defensive walls in this region. ${ }^{36}$ In the early years of the rule of Yazdgerd II (AD 43857), the focus shifted to the east and battling what the sources call the Kushans, probably the Huns. Yazdgerd II was stationed in Khurasan for some time until he was able to secure the eastern flank of the empire, and Bactria came under the control of the Sasanians. He then moved towards Armenia and Albania, as the defence of the Caucasus from the Huns moving westward was imperative, a campaign which also involved the Romans. ${ }^{37}$

Although there is a strong possibility that Sasanian settlement expansion in Mughan Steppe occurred during the reign of Yazdigerd II, it is known that other Sasanian kings such as Kawad/Qobad I (AD 488-96, 498-531) and Khusro I Anushirawan (AD 531-79) also carried out large-scale projects. To achieve all such projects, labour investment was critical. According to Adams, ${ }^{38}$ labour resources had a great place in Sasanian policy for infrastructure of the country, in addition to Sasanian armies. Population was obviously a significant issue and has an important place in planning and structuring city-building and irrigation construction, particularly in terms of the labour required for the construction of these massive features, their maintenance, and the intensification of agriculture that was both facilitated and required. According to Boserup's ${ }^{39}$ widely cited theory of the systematic relationship between population growth and agricultural intensification, an irrigation strategy can be a response to population pressure, and the adoption of irrigation should have enabled Mughan Steppe farmers to support a larger population by increasing the amount of crop yield per hectare of cultivated land. However, given the apparent lack of permanent settlement in the pre-Sasanian period it appears that the irrigation system on the Mughan Steppe was not an indigenous solution to subsistence problems, rather it was an imposition by central government; essentially a top-down phenomenon. 40

Our knowledge about local subsistence before and at the time of the Sasanian land-development project is nonetheless limited. There are some hints about nomadic groups on the Iranian Plateau during the

36 Aliev et al. 2006: 144, 175; Kettenhofen 1996; Kudriavtsev 1993: 23.

3) Daryaee 2009: 23.

38 Adams 2006: 22-23.

39 Boserup 2005.

40 Thurston and Fisher 2007: 6. 
period of the Sasanian Empire, but there is no evidence for the situation on the Mughan Steppe. ${ }^{+1}$ The establishment of a massive irrigation system following the same pattern as in Mesopotamia and Khuzestan might have been a new and unique experiment for both the Sasanian Empire and the pre-existing population of Mughan, and probably required engineers and skillful labourers in order to get these projects done.

According to some sources, particularly the Khudāy-nāmeh, large-scale population transfers were a significant part of the colonisation programme of the Sasanian Empire. In several cases we are informed about population transfers in which "people from the East" were settled in Hisar-Shapuhr, while 12,000 Iranians were brought by Shapuhr II to Nisibis, and systematic deportation of captives followed various wars. In his inscription at Naqsh-e Rustam, Shapuhr I states that he brought Roman captives and "non-Iranians" to Fars, Parthia, Khuzistan and Mesopotamia and resettled them in areas under direct government control. ${ }^{42}$ Morony argues that because of labour shortages caused by drought, famine, disease and warfare, the Sasanian Empire needed to deport the population of conquered cities such as Dara, Apamea, etc. and repopulate the above-mentioned regions. ${ }^{43}$

The construction of the fortified structures and irrigation networks on the Mughan Steppe would have required skillful labour and engineers. Given the population redistribution policy of the Sasanian Empire, it is very likely that one of the destinations of deportees may have been the Mughan Steppe. The entire settled population of the Mughan Steppe need not have been brought by the state from outside. and some of the required labour could have been secured through settling the transhumant/pastoral nomadic groups who lived in the region. Either way, these construction projects undoubtedly disrupted the subsistence practices of the transhumant/pastoral nomadic groups.

It appears that the Islamic conquest of the southeastern Caucasus region did not impact on the irrigation system that made use of the river-terrace edge. and the excavations at Ultan Qalası show that its fortifications continued in use. The soundings to date are too small to present a broad picture, but Islamic historians of the tenth century describe a city (known as Warthān) as a bustling economic centre with a large mosque outside

41 Daryace 2009: 40-41.

42 Christensen 1993: 69.

43 Daryaee 2009: 79. the city walls. ${ }^{44}$ On the northern side of the Aras, the city of Baylaqan also remained an important centre. 45 However, the $80 \mathrm{~km}$ long irrigation system which ran along the edge of the uplands appears not to have survived far beyond the late Sasanian period. The Mughan Steppe Archaeological Project survey recovered none of the Islamic sherds which characterise the upper phases of the soundings at Ultan Qalası on these fortified settlement complexes that lie along the southern edge of the plain. The same seems to have occurred with the irrigation canals and fortified towns that have been explored in the surveys of the Mil Steppe to the north of Aras River and the eastern Mughan Steppe in the Republic of Azerbaijan. ${ }^{46}$

The surveys and excavations of the Mughan Steppe Archaeological Project are providing new insight into the strategies used by the Sasanian Empire in dominating and maintaining frontier regions. The stratigraphic and chronological evidence from Trench 1 at Ultan Qalası suggests that the citadel was most likely founded around the mid-fifth century AD and remained occupied until the Early Islamic period, at least until the early eighth century. Although Trench 1 revealed good evidence for the development of the site and its chronological sequence, a single small trench is obviously insufficient for determining the stratigraphy of such a large site, and future excavations will establish the nature of the stratigraphy in different areas of the site. In addition, Trench 1 will be expanded to the inner side of the Citadel in order to obtain more material from the earliest and also the upper phases, which had been damaged by the bulldozer. Although there are clear spatial relationships between the fortifications and the canal systems, the relationship between the two is also an obvious area for further investigation.

At present, it is clear that Ultan Qalası was subjected to two big floods of the Aras River during its life. The second flood, which appears to date to the late Sasanian period, was more destructive, and led to the construction of a second citadel wall to reinforce and secure the inner city. It was presumably after the construction of this second wall that the city faced the Muslim Conquest. We do not know under what conditions and for how long exactly the city survived after the political and military collapse of the Sasanian Empire. but based on the architectural remains and the

44 Le Strange 1905: 176.

45 Bosworth 1990.

to Ahmador 1997: 19-22 
limited ceramic material recovered from the excavations, it appears that the city survived under slightly different conditions possibly as late as the tenth century.

\section{Acknowledgements}

This paper benefited from comments and criticism from C.C. Lamberg-Karlovsky, Jason Ur, Cameron Petrie and three reviewers for IRAN for which I am very grateful. All errors of course remain my own.

\section{Karim Alizadeh \\ Department of Anthropolog. \\ Harvard Universit. \\ 11 Divinity Avenue \\ Cambridge, MA 02138 \\ USA \\ alizadeh@fas.harvard.edu}

\section{Bibliography}

Adams, R.McC. 2006. "Intensified Large-scale Irrigation as an Aspect of Imperial Policy: Strategies of Statecraft on the Late Sasanian Mesopotamian Plain", in J. Marcus and C. Stanish (eds.), Agricultural Strategies. Cotsen Institute of Archaeology, Los Angeles: 17-37.

Ahmadov, Q. 1997. Qadim Berlaqan. Azerbaijan Dovlat Nashriyati, Baki.

Alden, J. and Balcer, J.M. 1978. "Excavations at Tal-i Malyan". Iran 16: 79-92.

Aliev, A.A., Gadjiev, M.S., Gaither, M.G., Philip. L.. Kohl. R.M., Magomedov and Aliev. I.N. 2006. "The Ghilghilchay Defensive Long Wall: New Investigations", Ancient Hest \& East 5(1-2): 143-77.

Alizadeh. K. 2006/1385. "Stratigraphy at UItan Qalası. Mughan Steppe". Archaeological Reports 5: 91-114 (in Persian).

- 2007a. "Excavations at Nadir Tepesi. Aslanduz. Mughan Steppe". Archaeological Reports, on the occasion of the 9th Annual Symposium on Iranian Archaeology December 9-12, 2007, 7(vol. 2): 263-85 (in Persian).

- 2007b. Preliminary Report of Archaeological Excanations at Ultan Qalasi, Mughan Steppe-drckahil Province. First and Second Seasons, Iranian (enter for Archaeological Research. Tehran (in Persian with English abstract).

Alizadeh, K. and Ur, J. 2006. "Mughan Steppe Archaeological Project, Ardabil Province" (Prozheh-ye Bastanshenasi-ye Dasht-e Moghan, Ostan-e Ardebil). Archacologrical Repoits 4: 49-56 (in Persian with English abstract).

- 2007. "Formation and Destruction of Pastoral and Irrigation Landscape on the Mughan Steppe. North-western Iran". Antiquity 81(311): 148-60.
Boserup. E. 2005. The Conditions of Agricultural Growth: The Economics of Agrarian Change under Population Pressure, Aldine Transaction, New Brunswick and London.

Bosworth. C.E. 1990. "Baylaqān", in E. Yarshater (ed.), EIr Vol. 4 (1), Mazda Publishers, Costa Mesa, California: 2.

Bronk Ramsey. C. 2007. Oxcal 4.0 manual. Oxcal Program v4.0. http:/cl 4.arch.ox.ac.uk/oxcalhelp/hlp_contents.html

Chaumont. M.L. 1985. “Albania”, EIr Vol. 1(8): 806-10.

- 1989. "Balāsagān", i. In Pre-Islamic Times EIr Vol. 3(6): 580-82.

Christensen. P. 1993. The Decline of Iranshahr: Irrigation and Environments in the History of the Middle East, $500 \mathrm{BC}$ to $A D$ 1500. Museum Tusculanum Press and University of Copenhagen: Copenhagen.

Daryaee. T. 2009. Sasanian Persia: The Rise and Fall of an Empire. I.B.Tauris \& Co. Ltd. in association with the Iran Heritage Foundation: London and New York.

Frye. R.N. 1963. The Heritage of Persia, World Publishing Company. Cleveland and New York.

- 1977. "The Sasanian System of Walls for Defense", in M. Rosen-Ayalon (ed.), Studies in Memory of Gaston Iriet. Institute of Asian and African Studies, The Hebrew University of Jerusalem, Jerusalem: 7-15.

Gadjier, M.S. 1997. "Studies of the Fort Derbent Fortification Complex and Identification of the "Fortress Sul", in O.D. Lordkipanidze. B.A. Jorbenadze and A.A. Tchanturia (eds.). Archaeology of Cancasus: New Discoveries and Perspectives. The Center for Archaeological Studies of the Georgian Academy of Sciences, Tbilisi: 27-28.

- 2008. "On the Construction Date of the Derbend Fortification Complex". Iran and the Caucasus 12(1): 1-16.

- and Kasumova. S.IU. 2006. Srednepersidskie nadpisi Derbenta II reka, Izdatel'svaia firma "Vostochnaia literatura" RAN. Moscow.

Gignoux. P. 1986. "Anērān", in E. Yarshater (ed.), EIr Vol. 2 (1). Mazda Publishers, Costa Mesa, California: 30-31.

Hawaiian Agronomics Company International. 1971. The Study of Animal Husbandry and Agricultural Complex of Moghan Region: Reconnaissance Survey and Preliminary Investigation. Ministry of Agriculture. Animal Husbandry Organization. Honolulu and Tehran.

Hessari. M. and Akbari. H. 1384/2006. "Gozareshe Gamanezani-ye Tape Iydir, Aslanduz", Archaeological Reports 4: 13-29 (in Persian).

Karimian. H. 2010. "Cities and Social Order in Sasanian Iran-the Archaeological Potential". Antiquity 84(324): $453-66$.

Keall. E.J. and Keall. M.J. 1981. "The Qal'eh-i Yazdigird Pottery: A Statistical Approach". Iran 19: 33-80.

Kettenhoten. E. 1996. "Darband". in E. Yarshater (ed.), EIr Vol. 7. Mazda Publishers. Costa Mesa. California: 13-19.

Kleiss. H. 1986. "Beobachtungen an der Wallanlage von Leilan in West-Azerbaidjan". A.1/19:211-17.

Kudriartser. A.A. 1982. Drernit Derhent. Nauka. Moscow:

- 1993. Fe'odal'nui Derhent: puti i zakonomernosti razvitia goroda $1 \%$-seredine . $1 / I 1$ 1. Nauka. Moscow.

Le Strange. G. 1905. The Lands of the Eastern Caliphate: Hesopotamia. Persia. and Central Asia from the Moslem 
Conquest to the Time of Timur, Cambridge University Press, Cambridge.

Lukonin, V.G. 1983. "Political, Social and Administrative Institutions, Taxes and Trade", in E. Yarshater (ed.). CHIr. Vol. 3, The Seleucid, Parthian and Sasanian Periods, Cambridge University Press, Cambridge: 681-746.

Markwuart, J. 1931. A Catalogue of the Provincial Capitals of Ëränshahr (Pahlavi Text, Version and Commentary). Pontificio Istituto Biblico, Rome.

Miroschedji, P. de. 1987. "Fouilles du chantier ville royale II A Suse (1975-1977)", CDAFI 15: 11-134.

Mohammadi, M.R. 2004. Parthian and Sassanid Periods in Mughan Steppe: Based on Nader Tepe (Nadir Tepesi). Aslandouz, unpublished MA thesis. Department of Archaeology, University of Tehran.

Monteith, C. 1833. "Journal of a Tour Through Azerdbijan and the Shores of the Caspian". Journal of the Rolal Geographical Society of London 3: 1-58.

Omrani, R.H., Sauer, E., Wilkinson, T. and Nokandeh. J. 2008. "The Enigma of the Red Snake: Revealing One of the World's Greatest Frontier Walls". Current Horld Archaeology 27: 12-22

Pahlavi, M.R. 1345/1966. Enqelab-e Sefid (White Revolution), Pahlavi Royal Library, Tehran (in Persian).

Qouchani, A. 1383/2004. Ganjineh-ye Sekke-have .Makshufeh dar Shahr-e Rey, Iranian Cultural Heritage and Tourism Organization, Tehran (in Farsi).

Reimer, P.J., Baillie, M.G.L., Bard, E., Bayliss, A.. Beck. J.W.. Blackwell, P.G., Bronk Ramsey, C.. Buck. C.E.. Burr. G.S.. Edwards, R.L., Friedrich, M., Grootes, P.M.. Guilderson. T.P., Hajdas, I., Heaton, T.J., Hogg, A.G.. Hughen. K.A.. Kaiser, K.F., Kromer, B., McCormac, F.G.. Manning. S.W.. Reimer, R.W., Richards, D.A.. Southon. J.R.. Talamo. S.. Turney, C.S.M., van der Plicht. J., Weyhenmeyer. C.E. 2009. "IntCal09 and Marine09 radiocarbon age calibration curres.
0-50.000 years cal BP". Radiocarbon 51(4): 1111-50.

Ricciardi. R.V. 1970-71. "Sasanian Pottery from Tall Mahuz (North Mesopotamia)", Mesopotamia 5-6: 427-42.

Schweizer, G. 1974. "The Aras-Moghan Development Project in Northwest Iran and the Problem of Nomad Settlement", Applied Sciences and Development 4: 134-48.

Schnyder, R. 1975. "Keramik und Glasfunde vom Takht-i Suleiman 1959-1968", Archäologische Anzeigen 90: 18096.

Shahbazi. A.S. 2005. "Sasanian Dynasty", in E. Yarshater, (ed.), Elr (http://www.iranica.com/newsite/).

Shams Eshraq. A. 1369/1990. Nakhostin Sekke-have Emperaturi-ye Eslam, Stak Cultural Service, Isfahan (in Persian).

Tapper, R. 1979. Pasture and Politics: Economics. Conflict, and Ritual among Shahseran Nomads of Northwestern Iran, Academic Press, London and New York.

- 1997. Frontier Nomads of Iran: a Political and Social History of the Shahsevan, Cambridge University Press. Cambridge and New York.

Thurston. T.L. and Fisher, C.T. 2007. "Seeking a Richer Harvest: An Introduction to the Archaeology of Subsistence Intensification, Innovation, and Change". in T.L. Thurston and C.T. Fisher (eds.), Seeking a Richer Harvest: An Introduction to the Archaeology of Subsistence Intensification, Innoration, and Change, Springer, New York: 1-21.

Ur. J.A. and Alizadeh, K. in press. "The Sasanian Colonization of the Mughan Steppe, Ardebil Province. Northwestern Iran", in S.J. Simpson (ed.), Studies in Sasanian Archaeology: Economy: Industrn: and Material Culture, British Museum. London.

Whitcomb. D.S. 1985. Before the Roses and Nightingales: Excavations at Qasr-i Abu Nasr: Old Shiraz, Metropolitan Museum of Art. New York. 